\title{
CERAMIC-MAKING IN EARLY COLONIAL TIMES
}

After the Spanish conquest many indigenous crafts continued to be manufactured in central Mexico. From the scarce documentary information on those activities we can infer that during the first colonial decades the production or trade of native goods for native consumers in general did not attract the colonizers, who were looking for other means to make money. According to Gibson (1964:335), colonial secular authorities did not openly interfere in the course of indigenous crafts nor dedicated itself to their erradication. As we will see in this chapter, native ceramics of the early colonial period suggest that the technology of production was long maintained, even after important social and economic changes altered other parts of indigenous life. Archaeological research also shows that other common crafts continued with the same method of manufacture in the first post-conquest years, such as the production of obsidian cutting tools (Rodríguez Alegría 2008:39-40) and cloth (Brumfiel 1996).

On the eve of the conquest artisans and artists made a wide variety of objects, in many materials and styles, in which dexterity, creativity and aesthetics played important roles. This apparently continued into the colonial period as Spanish documents, otherwise so negative in reference to the character of indigenous people, recognize the good quality and inventiveness of their craftsmanship. As Friar Bernardino de Sahagún (1992, X:578), actually trying to make a statement in favor of the missionaries' teaching labor, wrote “... en los oficios mecánicos son hábiles para aprenderlos y usarlos ... como son oficios de geometría ... albañilería, y cantería, y carpintería ... todo esto tenemos por experiencia que tienen habilidad para ello y lo aprenden y lo saben, y lo enseñan, y no hay arte ninguna que no tengan habilidad para aprenderla y usarla." ${ }^{1}$ Nevertheless, the enormous impact of the conquest on essential aspects of indigenous life such as land tenure,

\footnotetext{
1 “... they are skillful to learn and practice mechanical trades ... such as geometry ... masonry, lapidary and carpentry trades ... we have experience about all this, that they are skilful for this and they learn and know and teach it, and there is no art in which they do not have ability to learn and to use." (Sahagún 1992, X:578).
} 
religion, language and the system of administration also had effects on the native crafts, such as ceramic-making.

Without diminishing its profound and dramatic consequences, the reduction of communal and other forms of indigenous land gave in my opinion a positive impulse to the well-established native craft production in early post-conquest times. The loss of land as a consequence of major population decrease after epidemics, appropriation by encomiendas during the mid-sixteenth century, reorganization and concentration of towns during the congregación orders at the beginning of the seventeenth century, and other means for transferring land to colonizers' hands (see Gibson 1964:257-264; Lockhart 1992: 142-176), certainly encouraged alternative forms of subsistence that were not based on agriculture. That is, documents suggest that by the end of the first colonial generation indigenous artisans were manufacturing both Mesoamerican and Spanish-style products, at least in urban contexts. On the one side, they made quotidian native goods, including ceramics, to provide the still well organized and well supplied local markets (see Sahagún 1992, VIII:475-476; Super 1988). On the other, Sahagún also mentions that there were indigenous peoples who were blacksmiths (1992, X:553), candle makers (1992, X:575) and shoe makers (1992, X:576). Also Motolinia says in his Historia de los Indios, written between 1536 and 1541 (Burrus 1973:145), that they were already elaborating Spanish garments such as doublets, waistcoats and breeches, as well as swords, gloves, glass, metal artifacts, bells, leather shoes, saddles and bellows (Motolinia 1914:217, 1970:98). Although Sahagún's and Motolinia's comments do not give clues on how widespread the production of Spanish-style goods by indigenous craftpeople was, it is possible that this was accepted by the Spanish colonial administration in the first years after the conquest, as it was necessary to supply the cities. However, several decades later documents evidence the creation of guilds of Spanish artisans and regulations to protect the colonial market. For example, the Mexico City cabildo proceedings from February 1st of 1552 announced the prohibition for Spanish craftsmen to buy indigenous-made products with the purpose of reselling (Novelo 2007:96). This suggests that the production of Spanish-style objects by indigenous artisans became in some way problematic. Thus, before the end of the sixteenth century several Spanish craft guilds were organized in the city (see Carrera Estampa 1954). It seems that the first colonial potters' guild appears relatively late. The first documentary reference for a pottery guild is 
the list of regulations of 1653 for Majolica ware production in the city of Puebla (see López Cervantes 1976:15). One of its purposes was to protect Spanish artisans from other potters who apparently were also manufacturing that kind of pottery.

The introduction of Christian doctrine and the associated elimination of indigenous religious manifestations (see Burkhart 1989; Gibson 1964:99-235; Gruzinski 1993:146-284; Lockhart 1992:205243) might also have had an impact on the Mesoamerican ceramic craft. In late pre-Hispanic times ceramics had a large variety of functions. As we can recognize from their morphology and archaeological context, the majority was for domestic uses, but there was also a vessels' repertoire for ritual purposes, such as censers of different shapes and fine vessels with pictographic decoration for feasting and offering (see Hernández 2005, 2010). Besides, archaeological remains evidence that common objects were used as containers for offerings in diverse rituals, such as funerals (as grave goods), inauguration of public and private buildings (deposited in offering caches under the floor, e.g. López Luján 1993) or other rituals in temples (e.g., the Aztec new fire ceremony, see Elson and Smith 2001). After the conquest most of the indigenous public religious rituals were eliminated, and consequently the associated paraphernalia disappeared. The typical pre-Hispanic censers with long handles were still used in urban centers of the valley of Mexico as well as in rural areas (at least in the region of Otumba) during early colonial times but they had disappeared by 1620 (Charlton et al. 2007:455). Nevertheless, the practice of burning resins during religious celebrations did not vanish; it became an important part of the indigenous Catholic ceremonialism, as we can still observe in present-day indigenous communities. Vessels decorated with religious and ritual pictography also disappeared. Polychrome wares with pictographic decoration were still made and used in the valley of Mexico and Cholula after the conquest, as is evidenced by a few examples in colonial contexts, and, as we will see later, by some decorations and vessel shapes with European influence (Lind 1987:23-27). However they disappeared by 1650 according to absolute dates from associated contexts (Lind 1994:81). In this case not only the decoration was lost, but also the practice of using vessels decorated with meaningful texts in diverse ceremonies disappeared. In addition, the custom of placing offerings, such as ceramic vessels, to the dead was lost when the Catholic funerary rituals were imposed. Thus, indigenous 
ceramic-making after the conquest was concentrated on the production of quotidian objects.

The introduction of the Spanish language, and its imposition as lingua franca throughout Mesoamerica, also transformed the nomenclature system for ceramic forms and sizes, as we will see below in the section devoted to vessel shapes. The colonial administrative structure also had general effects on indigenous ceramic manufacturing. That is, the end of the Aztec empire resulted in the disruption of the welldeveloped long-distance and interregional exchange of goods characteristic of the last pre-Hispanic period (see Smith 1990), which also included ceramic wares. Also the separation in early times, at least in principle, of the indigenous and Spanish population in different sectors of the city, and even in different settlements, probably promoted the separation of indigenous-style and Spanish-style ceramics. For example, La Traza, an area that covered more or less a hundred blocks around the metropolitan cathedral in the center of Mexico City, was meant to be for public buildings of the colonial government and Spanish habitation (Flores 1970), although indigenous peoples continued living and working in this area after the conquest (Rodríguez Alegría 2002:164-168). In contrast, the houses of indigenous and other people were as a rule in the peripheries. There were as well indigenous settlements, such as Cholula, and settlements founded for Spanish occupation, such as Puebla. This separation that promoted differentiation of habits and material culture, likely also provoked the separation of indigenous-style and Spanish-style ceramics (see Charlton et al. 2005:62). At the same time, this segregation, together with the structure of the colonial social order, promoted in my opinion that in indigenous society luxury expressions and status symbols changed. Instead of the traditional feather works and polychrome ceramics, Spanish objects became highly valued and desirable. For example, Rodríguez de Alegría (2008:39) mentions that a document from 1641 granted permission to an indigenous elite from Xaltocan to ride horse back, carry sword and wear Spanish clothing.

Despite all these colonial changes, the indigenous community was maintained as the main social and political unit for regulating the life of native people and the interaction between colonizers and colonized (Lockhart 1992:15). That is, the local organization and its self-contained parts-such as neighborhoods, extended families and nuclear families-continued with few changes during the first colonial century. Thus, many social institutions, ritual practices and modes of sub- 
sistence deeply embedded in the community were maintained. This was probably the case for many craft industries based on family workshops, such as ceramic-making, which still today is a family activity and is associated to particular communities. However, the congregación orders of 1603, which relocated the surviving rural population decimated by early epidemics, altered the panorama of the indigenous communities (Knight 2002:27-29). Few larger communities were retained as centers, while smaller and dispersed settlements were congregated in these centers or in new locations (Lockhart 1992:44-46). This modified land tenure and the organization, harmony and identities of the indigenous corporation. According to Lockhart (1992:44), often the moved population retained their cohesion in the new town, becoming a new neighborhood, but on occasion the moved people were separated into several settlements or was assimilated to other groups in the new location. Thus, around 16401650 (Lockhart 1992:427-430) indigenous communities began to transform parts of their ancient structure, and this promoted that Spanish elements penetrated more profoundly in their organization. As we will see later, indigenous ceramics also evidence more profound changes about that time.

\section{Sources to study early colonial ceramics}

As is the case for the pre-Hispanic period, no other region of Mesoamerica has been as extensively explored as the valley of Mexico in order to shed light on the colonial era. This is due to the existence of a vast corpus of documents referring to this area, and because major public works and conservation of colonial buildings have motivated archeological rescue of colonial contexts. Also a main reason is that Tenochtitlan/Mexico City was the core of the colonial world, where the interactions between different components of the colonial society were more vivid and had more material manifestations. In other regions of Mesoamerica there is also documentary information on the colonial era, but it is not as extensive as in the valley, and also it is often not accompanied by archeological exploration. The same applies for our knowledge on ceramic-making during that time; most of the comparatively scarce archeological research and documentary information is concentrated on the valley of Mexico. 
Colonial chronicles and other historical documents, although abundant in central Mexico, offer very little information on indigenous ceramic manufacturing. A few manuscripts refer to Spanishstyle ceramics, such as the Ordenanzas de Loceros, a list of regulations for potters specialized in Majolica wares in Puebla made in 1653. There are also a few brief comments in Mexico City cabildo proceedings from the mid-sixteenth and seventeenth centuries about rules for potters specialized in Spanish-style wares. In addition, in correspondence of colonial authorities there are a small number of observations on this craft. However, to my knowledge, the only extant early colonial manuscript directly referring to the manufacture of indigenousstyle ceramics is the one named by Robert Barlow (1951) Códice de los alfareros de Cuauhtitlan. ${ }^{2}$ It is a large strip of European paper with illustrations, pictographic writing and short Spanish texts. According to that text, this document was presented in 1564 by four potters of Cuauhtitlan to the judge of the same town in order to complain about the alcalde mayor, who did not fully pay them for an order of pots. This manuscript provides information about the kind of vessels produced at that time, their price and the situation of indigenous potterymaking in the early colonial period.

Archeological research of early colonial contexts in the valley of Mexico has been the result of different kinds of projects. First, major public works, such as the subway or the city's deep drainage, but also other building activities in different locations, have involved rescue excavations. Often archeologists have obtained large collections of ceramics and other materials of the colonial period. Second, several large conservation programs to restore convents and other colonial buildings, such as the ex-convento de San Jerónimo (Fournier 1990) or the Catedral metropolitana (Matos Moctezuma 1999), have also been interested in collecting and studying archeological ceramics. Also many archeological explorations focused on pre-Hispanic remains have obtained colonial materials as in Mexico City pre-colonial deposits are usually covered with large colonial deposits. This was the case, for example, for the excavations in the Templo Mayor (Matos Moctezuma 1982). In addition, the large-scale projects of surface survey made in the 1960s and 1970s that covered most of the valley of

2 The Códice de los alfareros de Cuauhtitlan is deposited in the Bibliothèque Nationale de France, in Paris, where it is cataloged as Codex Mexicain No. 109 of the Aubin-Goupil collection. 
Mexico, although focused on pre-Hispanic remains, also briefly documented evidences and materials of the contact period.

Thanks to all these explorations, there are available several collections of colonial ceramics, although they are not as large and representative as pre-Hispanic collections. Also they are less studied and understood than pre-Hispanic ceramics. Nevertheless, the existing assemblages of post-conquest ceramics from the valley of Mexico permit us to obtain insights into their technology of manufacture. These ceramics are, however, in several aspects problematic. Archeological materials from sealed deposits corresponding to the period of contact are scarce; and the same is the case for deposits associated to short intervals of time between 1521 and 1650 (Charlton et al. 2005:55). For this reason, it is difficult to define a chronological sequence for the early colonial period based on ceramics. Most archeological materials come from construction fills throughout the city, which as a rule are mixed due to intensive building activity during the five hundred years after the conquest. Also the sampling of ceramics is irregular. While some parts of the valley are well represented-such as La Trazaother peripheral or more rural locations are not documented. Moreover, most of the study of colonial ceramics has concentrated on Spanish-style vessels, such as Majolica wares, as they are easy to associate to short intervals of time according to their painted decoration (e.g., Fournier 1990; Lister and Lister 1978, 1982; López Cervantes 1976; Rodríguez Alegría 2003). There have been detailed studies of indigenous-style ceramics (e.g., Charlton et al. 1995, 2005, 2007; Fournier 1997), though they have given more attention to decorated ceramics. In fact, common plain wares as well as simple glazed wares for domestic purposes are difficult to date as they appear during the whole colonial period and continue to the present time. Also they seem to present little variation in morphology or surface finishing through time, and decoration - the aspect of ceramics that can be easily and rapidly changed-is often not present. In addition, it is not valid to directly correlate indigenous-style ceramics with indigenous users, nor Spanish-style ceramics with Spanish users, as we know at the present that the patterns of distribution of those ceramic traditions were more complex (see Rodríguez Alegría 2005). Also we began to recognize that urban and rural contexts in the valley of Mexico had di

genous-style ceramics had several changes in the first colonial decades and coexisted with Spanish-style ceramics, in rural settlements vessels 
changed at a much lower rate and Spanish-style ceramics were scarce (see Charlton et al. 2005).

The direct association of a particular ceramic style with a particular culture is in my opinion always problematic, as the use of material culture is often determined by economic and social factors rather than by ethnic or cultural affiliation. Certainly economic, social and cultural aspects are associated but there are often exceptions. In colonial situations such as the case of Mesoamerica this can be even more problematic given that colonial society was heterogeneous; it was conformed by more social groups than solely the indigenous peoples and the Spaniards. Also material culture became an important marker of the users' social and economic place in the new society, rather than of cultural affiliation. For example, indigenous caciques in the Mixtec area (Lind 1987:111-112) and native traders in the Soconusco region (Gasco 1992) used Spanish-style objects, while in houses of the Spanish sector of Mexico City - La Traza-have been found ceramics of indigenous-style, such as Red Wares (Rodríguez Alegría 2005). Thus, the polar separation between indigenous-style and Spanishstyle ceramics does not reflect the social complexity of the colonial society at that time, and probably also does not reflect the situation of the pottery technology. This will be explored in this chapter.

In other regions outside the valley of Mexico colonial contexts and ceramics have been much less explored. For the valley of PueblaTlaxcala, there have been a few brief studies of colonial ceramics, considering both indigenous and Spanish-style vessels, coming from brief rescue excavations in colonial locations in the city of Puebla (Hernández 2000a, 2000b; Hernández and Reynoso 1999) and Cholula (Sáenz 2004). Also Florencia Müller (1981) made a description of the colonial pottery recovered in a large-scale surface survey conducted in Tlaxcala and parts of Puebla during the 1970s. She also made a brief revision of colonial materials from Cholula (Müller 1973). However, archaeological projects focused on colonial contexts that also include detailed study and publication of ceramics, have not been conducted in this region to date. For the valley of Morelos the situation is similar. To my knowledge, only one restoration project has also included collection and study of colonial ceramics, and has made the information available. It is the conservation of the palace of Cortés in Cuernavaca (Charlton et al. 1987). Also detailed archaeological investigations of colonial contexts in the valley of Toluca have not been published. Therefore, the study of indigenous ceramics from the colonial period 
in central Mexico has been mainly focused on the valley of Mexico. This is also the case in this study. Data from other regions complement the information from the valley.

Thus the majority of knowledge on indigenous colonial ceramics is based on archeological research, in particular on the study of the ceramic remains themselves. In the present work the documentation of the different manufacturing stages of indigenous-style ceramics during the colonial period are in major part based on consultation of archeological collections from numerous contexts in Mexico City deposited in the Departamento de Colecciones Comparativas (known also as Ceramoteca) at INAH in Mexico City. These collections consist of selected samples of diagnostic ceramics found in colonial locations all through the city. Some locations with large collections of indigenous and Spanish-style ceramics were: Casa del Marqués del Apartado excavated by Elsa Hernández Pons in 1984-1987; Casa Limón No. 16 excavated by Octavio Corona Paredes in 1987-1990; Real Seminario de Minería, excavated by Arturo Guevara Sánchez in 1989; ex-convento de San Jerónimo excavated in 1994; ex-convento de Bethlemitas, excavated in 1993-1995 and 1998; San Idelfonso; Bancomer, Coyoacán, studied by Silvia Mesa Dávila; Plaza Banamex; Complejo Hidalgo, excavated by Francisco González Rul in 1979-1981; Catedral Metropolitana, ceramics studied by Constanza Vega Sosa in 1975-1976, and Garibaldi, explored in 1973. These collections were samples of the most representative ceramics found in the places explored. The size and variety of the samples did not respond to any statistical principle and do not provide clues on the total amount and variety of the ceramics excavated in every location. The archaeologists who made them only wanted to show illustrative examples to locate in time and space the collection. In addition, for most of these explorations and analysis of materials, reports are not available. Therefore we do not have information on the specific context of deposition. In spite of these restrictions, those ceramic collections represent a wide and varied sample of the pottery made and used in the city during the colonial period. Thus, they are useful to explore the technology of manufacture. For the present study, these samples were consulted in order to obtain indications on method of forming, firing technology, surface finishing, decoration and morphology of colonial ceramics. For this reason, quantification of specimens or statistical analysis was not relevant. As the majority of the examples showed temporal diagnostic attributes, that are characteristics of the late pre-Hispanic period, the early colo- 
nial period or the late colonial period, it was possible to allocate temporally particular details of the method of manufacture. The consult of those collections was complemented by literature research.

\section{Organization of ceramic production}

Documentary information about towns specialized in pottery-making in the valley of Mexico during the early colonial period is scarce. According to Gibson's exhaustive archival research (1964:350), pottery manufacture at that time was characteristic of Huitzilopochco, Azcapotzalco and Xochimilco. The major producer of the valley was the town of Cuauhtitlan, north-west of Mexico City. At the time of the conquest it was located on the shores of Lake Xaltocan. Clay deposits were, and still are at the present time, abundant and visible at the surface. In the annals of Cuauhtitlan it is mentioned that the pottery industry arrived late in the pre-Hispanic period to this town; that is, after it was conquered by Azcapotzalco during the middle part |of the fourteenth century (Codex Chimalpopoca 1975:313). Gibson (1964:350) also comments that there are documentary notices of the seventeenth and eighteenth centuries on the pottery of this town. Thus it seems that the importance of Cuauhtitlan in this industry was maintained at least until the late part of the colonial period.

The study of clay composition of early colonial ceramics by means of neutron activation analysis shows that pottery continued to be produced in different parts of the valley of Mexico. That is, ceramics were made at least in six areas: Teotihuacan valley, Texcoco, Chalco, Zumpango, Cuauhtitlan and Tenochtitlan (Garraty 2006a:220). This technological study also indicates that pottery-making was continued in Otumba (Charlton et al. 2008:260). However, the patterns of distribution were apparently modified. The composition of vessel clay suggests that ceramics were distributed more locally within the valley (Charlton et al. 2008:263; Garraty 2006a:218). Also it seems that Tenochtitlan was no longer the main producer as was the case during the last pre-Hispanic centuries (Garraty 2006a:226). All this implies that the market system of the Aztec empire collapsed after the conquest. According to Garraty (2006a:222), the distribution of ceramics

\footnotetext{
${ }^{3}$ Paragraph 128 in original manuscript, Anales de Cuauhtitlan.
} 
across the valley during the Early colonial period is more similar to that of the Early Aztec period, before the empire came into existence.

For the neighboring regions of the valley of Mexico there is little documentary information on places of ceramic manufacture in early colonial times. Cholula, in the valley of Puebla-Tlaxcala, was a wellknown ceramic-making place during late pre-Hispanic times and in the contact period, as Díaz del Castillo mentions (1980:149). However, it seems that in the second part of the sixteenth century pottery-making was no longer a city's renowned activity. Gabriel de Rojas, corregidor of the city at that time and author of the meticulous Relaciones Geográficas of Cholula, mentions that "... antiguamente, en sola esta ciudad se usaba hacer jarros, ollas, escudillas ..."4 (Rojas 1985:128). Nevertheless, in his description of the city as it was at the time of writing the Relación, in 1581, he did not mention this craft again though he describes in some detail other industries and trades practiced there. This may even suggest that pottery was no longer produced in the city. At present pottery is not produced in this place. Rojas (1985:126) comments that Cholula lost a large part of its population after the epidemics of 1540 and 1576. That is, from the ancient forty thousand inhabitants, the city was reduced to nine thousand full tributaries. Thus it is possible that the enormous population decrease provoked a rupture in the transmission of knowledge and pottery-making disappeared. Still, indigenous-style colonial ceramics were used in the city, such as the red ware common at that time in the valley of Mexico. This kind of pottery was even used in convents and churches as remains of vessels in refuse disposals show (Plunket et al. 1994; Sáenz 2004). Ceramics could arrive in the city through its traders and large market, which were regionally well-known as Rojas mentions (1985:144).

Indigenous-style pottery was probably made in domestic workshops, as we do not have any evidence that may suggest the contrary and this is the pattern at the present time. This might imply that the transmission of knowledge was family-based. The Códice de los Alfareros de Cuauhtitlan suggests that, at least in this town, potterymaking was an activity in which men participated, as the claim is presented by the potters Agustín Vásquez, Andrés Bonifacio and Francisco Hernández. At present when pottery is the most important source of income of a family it is practiced by the family heads; some-

4 "In the past, in this city people used to make pitchers, jars, bowls ..." (Rojas 1985:128, my translation). 
times only the men but sometimes all the family members (e.g., Engelbrecht 1987:299-314; Papousek 1984:485). In contrast, when pottery only complements the resources obtained by agriculture or other means, it is often practiced mainly by women (e.g., de la Vega 2007). In Cuauhtitlan pottery-making was an important and renowned activity as a reference of Juan Suárez de Peralta (1990:185) in his Tratado del Descubrimiento de Indias written in 1589 indicates: "Alonso de Avila [encomendero of Cuauhtitlan] invited the marquise to a fine feast ... and then the dinner, which was very well made and very expensive, in which was served with vases that they call alcarra$z a s$, and earthenware jars, and these were made in Alonso de Avila's town in Cuauhtitlan where they made a lot of pottery ${ }^{50}$. Thus, we can assume that the men who presented the claim to the judge were also active potters. In addition, the manuscript of Cuauhtitlan suggests that in this town pottery had another level of organization outside the family. According to the transcription of Rosanna Woensdregt the document states:

En el pueblo de guavtitlan [?] diez dias del mes de abril de myll e quinientos e sensenta e ocho anos parecieron antemi alonso dsolozo [?] juez de Residencia en este dicho pueblo agustin vazquez e andres bonifacio e francisco hernandes e juan damian alguazil de los olleros deste dicho pueblos e presentaron esta pintura e dixeron que juan suares de per[al]ta [?] alcalde mayor e asydo en este dicho pueblo [?] les mando hazer todos estos jarros e tinajas e alcarrazas desta pintura en el tiempo que fue tal alcalde mayor en est dicho pueblo ... (Códice de los Alfareros de Cuauhtitlan).

The document suggests that Juan Damian was alguazil of the potters, which may imply that there was an authority representing the craftspeople of the town. This could well be possible as Sahagún (1992, IX:516-519) mentions that pre-Hispanic fine crafts such as feather work and lapidary were highly organized, and the artisans had particular feasts, patron gods and temples. It is also possible that the colonial craft guilds established in urban contexts of Mexico, following the model of the European guilds at that time (see Carrera Estampa 1954), had some echo in rural locations such as Cuauhtitlan. However, we do

\footnotetext{
5 "Convidó Alonso de Ávila a la marquesa a una muy brava cena ... y luego la cena, la cual fue muy cumplida y muy costosa, en la que se sirvieron unos vasos, que allá llaman alcarrazas, y unos jarros de barro, y éstos se hicieron en el pueblo de Alonso de Ávila en Cuauhtitlan, que se hace allí mucho barro ..." (Suárez de Peralta 1990:185, my translation).
} 
not have more documentary information about the organization of production of indigenous-style ceramics. Pottery like other craft productions, as Lockhart found (1992:176), did not reach levels of legal action in the altepetl. For this reason, they are rarely represented in documents.

We still do not exactly know when the Spanish ceramic technology arrived to Mexico, as this industry is scarcely mentioned in early colonial documentation, and ceramic remains do not offer fine chronological details. It seems that after the conquest the Spanish colonizers wanted to maintain their European eating habits, and for them this implied eating from the same vessels used at home, such as glazed wares and white tin-enameled Majolica wares. In the beginning Spanish ships brought loads of ceramics to the Americas. For example, in the early settlement of La Isabela founded by Columbus in 1493 in the Dominican Republic have been found typical fifteenth century Andalusian service wares, which still evidence Arabic stylistic traits (Deagan and Cruxent 2002:139). After the conquest Spanish ceramics also arrived to Mesoamerica (see Fournier 1996:452; Lister and Lister 1978; Sánchez 1996), but probably not in large quantities and not common vessels as transoceanic transportation was costly and reserved for other basic items such as weapons, wine and oil (Sánchez 1996:128). In addition, after the establishment of the Manila galleon trade in 1573 a few Chinese porcelains arrived in Mexico City (Charlton et al. 2005:62; Lister and Lister 1978:10).

In a document sent by Alonso Figueroa, Chantre of Oaxaca, to Charles V in 1529 he states: "Con trabajo e ingenio alcancé el vidriado que no tenían, un plato en que comer sino venía de Castilla" 6 (cited in López Cervantes 1976:15). However, as he says, wares were still imported from Spain (López Cervantes 1976:15). A few later sources, the Florentine Codex (Sahagún 1961, X: 839) [apparently prepared as early as 1547 and completed in 1569 (D’Olwer and Cline 1973:193)], the Historia Eclesiástica Indiana (Mendieta 1980 [1571-1596]: 404) and a letter of Viceroy Lorenzo Suárez de Peralta dated in 1583 (Cervantes 1939: I, 18); show that by 1570s-1580s the production of glazed wares was already established in the colony. Thus, the first production of glazed wares in Mesoamerica occurred around 1529 and was well established by the end of 1560s. Mendieta (1980:404) also

\footnotetext{
6 "With work and talent I was able to make glaze, as they did not have a plate to eat if it did not come from Castile" (cited in López Cervantes 1976:15).
} 
mentions that a pottery master from Spain established in the colony. We can infer that he, or other Spanish potters, started a workshop for Spanish-style ceramics, such as Majolica ware, and introduced the potters' wheel. However, it is not clear when the first potters arrived, though the letter sent by Lorenzo Suárez de Peralta in 1583 to the alcalde mayor of Michoacan mentions:

... por cuanto por parte de los naturales de la ciudad de Patzcuaro, que son oficiales de hacer platos y escudillas de loza vidriada y otras piezas de barro, me ha sido fecha relación que la justicia de dicha ciudad, proveyó veedores de este oficio para que viesen y visitasen la obra que se hazía, para que siendo tal se pudiese vender y no lo siendo se los quitase y no se vendiese. Y agora estos indios olleros que no son ni han sido ni pueden ser oficiales de dicho oficio ni lo saben hacer dichos platos mal hechos y de donde se sigue fraude y engano ... y me pidieron les mandase dar y diese mandamiento para los que son tales oficiales usen el dicho oficio y no los olleros ...7 (Archivo General de la Nación, Ramo Indios, Vol. II expedient 718; López Cervantes 1976:15).

This shows that by that time not only the manufacture of glazed ware was well established, but also that indigenous potters were using this technique. However, both the indigenous and the Spanish traditions of ceramics were apparently produced in different workshops. The excavation of a colonial workshop from the end of the sixteenth century and beginning of the seventeenth century in the neighborhood of Santa Maria Cuepopan in Mexico City revealed that only Majolica wares were produced there (Gámez 2003:236). Also the guild regulations of the seventeenth century for Majolica potters of Puebla suggest that they produced only common and fine grade glazed. That is, the fifth statute states:

Que haya de tener separación los tres géneros de loza fina, común y amarilla, que se entiende ollas y cazuelas, y otros vasos, jarros colorados, no pueden hacer loza fina, ni común, menos que habiéndose examinado para ello de forma que cada uno ha de labrar, sólo el género

7 "... concerning the inhabitants of the city of Patzcuaro, which are officials in the trade of making glazed ceramic plates and bowls and other objects of clay, it was informed to me that the justice of the mentioned city, provided observers of this trade in order to observe and visit the works made, and in the case they were right they could be sold and if not they could be taken and not sold. And now this indigenous pot makers which are not and were not and cannot be officials in this profession and cannot make those wrong made plates and where fraud and tricks are followed ... and they asked me to give an order for those who are officials could practice this profession and not the pot makers ..." (Archivo General de la Nación, Ramo Indios, Vol. II exp. 718, cited in López Cervantes 1976:15). 
de que se examinarse, y no otro ninguno, si no es que se comprende todo en su examen ${ }^{8}$ (Novelo 2007:101).

Potters of Spanish-style ceramics also maintained different methods of manufacture, morphology and decoration. That is, they introduced the potter's wheel, which was not used in pre-Hispanic Mesoamerica; the lead and tin-based glaze to decorate ceramics, which was also unknown, and vessel shapes that were not produced before in Mesoamerica, such as particular forms of plates, cups and jars as we will see later. Thus, Spanish-style workshops were specialized in the manufacture of lead glazed vessels, and in particular in the so-called Majolica wares which were very popular at that time in Spain (see Pleguezuelo 1999; Sánchez 1994). These vessels were covered with lead glaze that was whitened and opacified by the addition of tin oxide (Lister and Lister 1982: vii). The first Spanish-style workshops for Majolica ware were established in Mexico City. According to the Listers (1978:22), this occurred around 1530s, considering the morphology and style of the vessels made. Afterwards the production was moved in the 1580s to the city of Puebla, where in the seventeenth century Majolica wares received a great impulse, and new shapes and colorful decorations appeared (see Lister and Lister 1984:87). The production became so significant that Mexican Majolica wares were exported to other Spanish colonies in the Americas (e.g., Duarte and Fernández 1980; Goggin 1968:223).

It seems that during the first generations after the conquest there were not many points of conflict between native and Spanish potters and between native potters and colonial authorities as the notorious scarcity of administrative documents and other written sources related to this topic suggest. The creation of pottery guilds and regulations in the seventeenth century suggests, however, that by the late colonial period Spanish-style workshops were competing with other pottery workshops. It also shows that ceramic-making-in particular the manufacture of Majolica ware-became a better remunerated activity that attracted the attention of colonial authorities, artisans and middlemen.

\footnotetext{
8 "It should be made a separation between the three grades of ware, fine, common and yellow, which is understood as the jars, cazuelas and other vases, red pitchers, they cannot made fine or common wares, at least they are examined for this in that way everyone can only produce the grade of ware for which he has been examined, and no other grade at least it is included in his exam" (Novelo 2007:101).
} 
In Mexico guilds and regulations for crafts with Spanish antecedent were early established by the colonial administration (see Carrera Estampa 1954; Castro Gutiérrez 1986; Pérez Toledo 1993). Already in 1525, Mexico City cabildo proceedings mention: "Este día los dichos señores ordernaron e mandaron que de aquí adelante ningún oficial que usare su oficio en está cibdad no sean osados de jugar a los bolos ni a la pelota en los días de hacer algo ..." " (Novelo 2007:95). Craft guilds were established in particular sectors of the city, their members were examined and had a hierarchy according to their knowledge and experience, and there were many rules for their work and products (Carrera Estampa 1954). This form of organization gave way to workshops not based on family relations but rather on occupation relations. That is, professionals and apprentices might be contracted in workshops to which they did not have any personal relation. This was a clear contrast to indigenous-style workshops based on the family. Likely this resulted in the fact that the two kinds of workshops developed different forms of personal relations and of knowledge transmission.

Nevertheless, it seems that indigenous-style workshops in Mexico City, at least for some professions, were also organized at corporate level. According to Gibson (1964:399-400), by the end of the sixteenth century some indigenous craft barrios were sufficiently organized to make a common appeal to the Spanish authorities; also among the candle makers procedures of examination and supervision were in operation in 1551. In addition, indigenous craftspeople were organized in cofradias, an institution which associated persons of same profession for the cult of the patron saint and for other social and religious purposes. This form of organization had a broad acceptance in indigenous society (Gruzinski 1990) and has been conserved until the present time in some places, even after guilds and regulations disappeared in the eighteenth century (see Castro Gutiérrez 1986).

\footnotetext{
9 "... concerning the inhabitants of the city of Patzcuaro, which are officials in the trade of making glazed ceramic plates and bowls and other objects of clay, it was informed to me that the justice of the mentioned city, provided observers of this trade in order to observe and visit the works made, and in the case they were right they could be sold and if not they could be taken and not sold. And now this indigenous pot makers which are not and were not and cannot be officials in this profession and cannot make those wrong made plates and where fraud and tricks are followed ... and they asked me to give an order for those who are officials could practice this profession and not the pot makers ..." (Archivo General de la Nación, Ramo Indios, Vol. II exp. 718, cited in López Cervantes 1976:15).
} 
Several stages of the early colonial process of manufacturing indigenous-style ceramics in central Mexico can be reconstructed from visible manufacturing traces on the vessels and from extant documents. Six stages of the process of ceramic-making will be here approached and compared with the situation in late pre-Hispanic times: (a) clay preparation; (b) vessel forming; (c) vessel surface finishing; (d) firing; (e) decoration, and (f) assembling vessel shapes. Most of this information came from the valley of Mexico as more archeological research on colonial contexts has been conducted in this area than in neighboring regions. For this reason, we will concentrate on the valley and, when possible, complement with available data from other places.

\section{(a) Clay preparation}

At present we have little information on clay preparation during early colonial times in central Mexico. Therefore we cannot yet resolve if there were differences in clay recipes between late pre-Hispanic and early post-conquest indigenous-style ceramics. The main reason is that most of the Late Aztec and early colonial occupations in the valley were inextricably mingled. Thus it is not easy to distinguish which vessels were manufactured in pre-colonial and which in colonial times. Also vessels decorated in Late Aztec style continued to be made during the first decades after the conquest (see Charlton et al. 2005, 2007); thus again, it is not easy to distinguish between pre- and postconquest manufacture. Nevertheless, observation of vessel fragments from contexts identified as early colonial shows that in general potters continued using the same clay recipes. The clay of vessels made in the valley still contains sand inclusions. Also bigger objects still have a higher percentage of sand than smaller objects, and Red Wares have finer texture than orange vessels for cooking and serving (Charlton et al. 2007: 448; Parsons 1966:213). Charlton and colleagues (2007:437) mention that in ocassions the clay of colonial orange wares for cooking is a little bit coarser than in pre-Hispanic vessels of the same kind, although in other cases the clay is the same as in Late Aztec times. They have also found that in rural contexts a higher percentage of orange cooking and serving vessels include vegetal fibers in the clay (Charlton et al. 2007:436, 440).

The application of lead glaze for decorating vessels was an early Spanish introduction. This technique had a wide acceptance by indigenous potters during the colonial period. As we will see in the section 
devoted to surface finishing, it seems it was established in indigenous workshops by the second part of the sixteenth century. At the same time, workshops specialized in Spanish-style ceramics also produced lead glazed wares, as glazed vessels show clear marks of being manufactured with the potter's wheel, which was distinctive of that kind of workshop. The clay of lead glazed wares looks similar to that of late pre-Hispanic Aztec wares; although in ocassions the clay of glazed objects is a bit more porous and apparently includes organic materials as temper (Charlton et al. 2007:486). At present we do not know if there were differences in clay recipes between lead glazed pots made in indigenous-style workshops and those made in Spanish-style workshops. Nevertheless, it is clear that glaze was added as decoration to indigenous-style vessels, which continued to be manufactured with the same clay recipes as in the past.

As in pre-Hispanic times, we recognize little variation in clay recipes throughout the valley of Mexico. Salt-making vessels, although very scarce after the conquest, are still made with the same distinctive clay mixture with high content of vegetal fibers (Charlton et al. 2007:455). An exception to this continuity is a distinctive and somewhat rare assemblage of vessels with red painting and feldspar-inlaid found since the early colonial period in the valley and in some places in neighboring regions such as Cholula and Cuernavaca (Fairbanks 1966). These vessels are similar in surface finishing to pre-Hispanic and colonial Red Wares, but they have in the surface inlaid fragments of feldspar. The clay of these vessels has sand inclusions as was typical in central Mexico. However, the study of the chemical composition of the clay suggests that these vessels were not made with clays from the valley, though it is not yet clear where they were manufactured (Rodríguez Alegría 2002, II: 491).

In Cholula clay recipes for common cooking vessels such as cazuelas, comales and braziers also seem to continue as in pre-Hispanic times. The observation of ceramics fragments from a refuse disposal in the parish church of San Andrés Cholula dated to the seventeenth and eighteenth centuries suggests that clay was blended, as in early times, with sand and basalt (Sáenz 2004:66). In contrast, lead glazed ceramics evidence two clay recipes; one is similar to the recipe used for non-glazed common cooking vessels, while the other is more compact and has little rounded black inclusions (Sáenz 2004:90). This may 
suggest that both kinds of vessels were produced in different workshops, or even in different locations.

In brief, present data suggests that clay recipes continued without evident changes after the conquest, at least in the valley of Mexico. Also some wares decorated with lead glaze were made out of the same clay used to produce cooking and other utilitarian vessels of indigenous tradition. In contrast, Majolica wares made in Mexico City and Puebla used other clay recipes. High quality vessels made in Mexico City, named fine grade Majolica in the guild regulations, were made with compact clay in which no inclusions are recognized with the naked eye. According to Rodríguez Alegría (2002, II: 442), chemical analysis suggests that the clay was a mixture of calcareous clays with clays traditionally used by the Aztecs. Common grade Majolica wares had more granular clay than fine grade wares (Rodríguez Alegría 2002, II: 446).

\section{(b) Vessel forming}

After the conquest potters of the valley of Mexico continued using the same methods of forming vessels. Remains of indigenous-style ceramics from contexts identified as early colonial show that vessels were made with horizontal molds. Also ceramics of indigenous-style with decorative or morphological traits characteristic of the early colonial period were made with horizontal molds. In the case of ollas, juncture marks show that they were made using two or three horizontal molds as in pre-Hispanic times (Figure 11). As in Late Aztec examples, on occasion one mold was used for the lower part of the body and another for the upper part which included the vessel's neck; in other cases two molds were used for the body and a third one for the neck. Also as in early times, bowls were made with one horizontal mold. Red Ware received a great impulse in colonial times; many new shapes and decorations appeared. Nevertheless, manufacturing marks visible on the vessels, such as junctures and differential compaction of the clay, show that they continued to be made with molds.

The first Spanish-style workshops for Majolica ware were established in Mexico City around the 1530s, considering the morphology and style of the earliest Majolicas produced in Mesoamerica (Lister and Lister 1978:22). Likely at the same time was introduced the potter's wheel to form vessels, as this implement was characteristic of that kind of workshops. Mexican Majolica vessels, as well as other vessels 

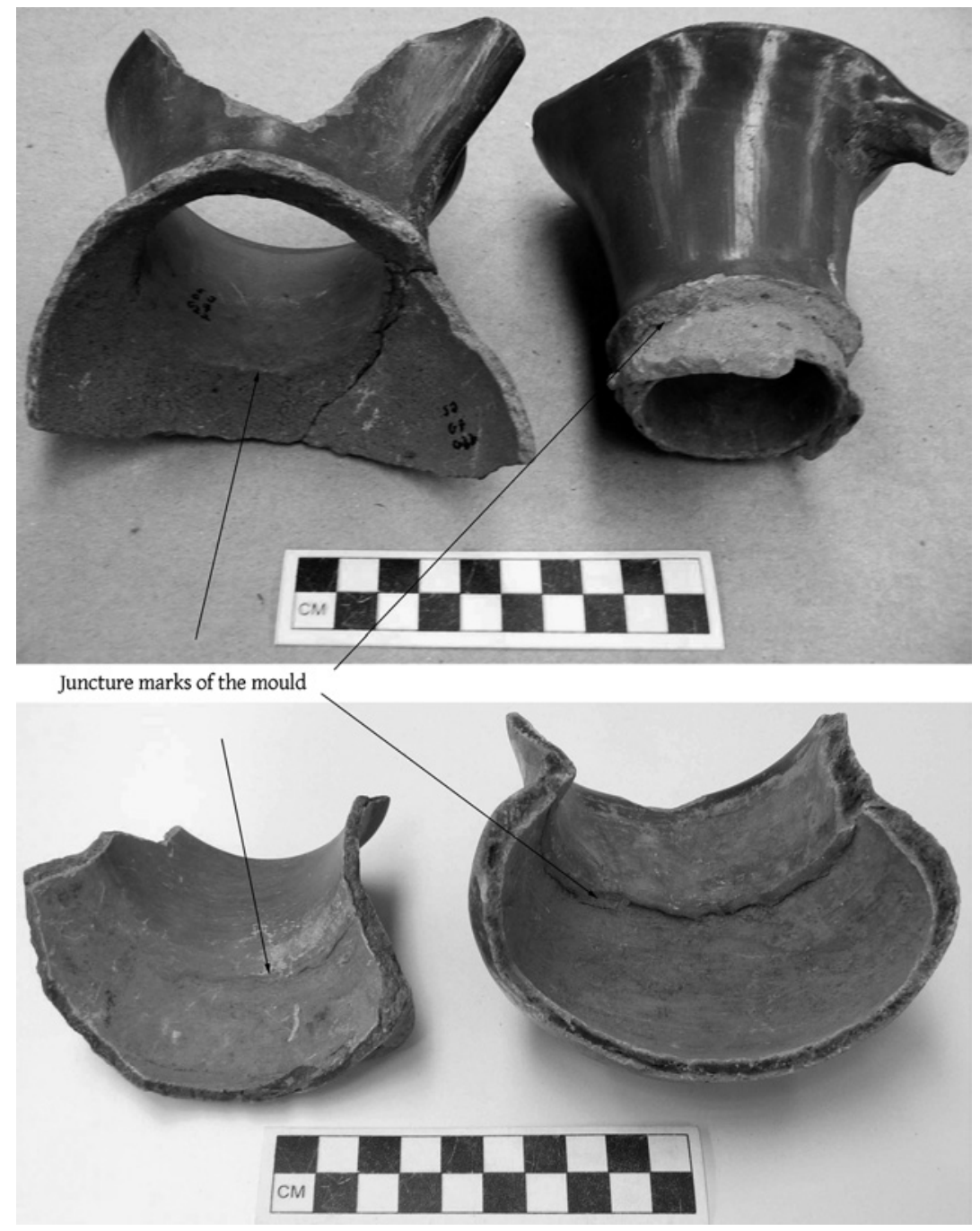

Figure 11. Fragments of ollas from the valley of Mexico with juncture marks showing that they were made using two or three horizontal molds as in pre-Hispanic times. 
made with the wheel, show the typical attributes associated with throwing, such as spiral rhythmic grooves and ridges on the interior of the base, compression ridges on the interior of the walls, or straight, parallel grit dragmarks on the base (Rye 1981:75). Forming vessels with the centrifugal force of the wheel was the common method for pottery manufacturing at that moment in Spain (Sánchez Cortegana 1994), and it had a long tradition in the old world. It was present in southern Levant as early as the beginning of the 4th millennium вС (Roux 2003:2).

In indigenous-style workshops the potter's wheel was apparently not adopted. We can propose several reasons for this. First, the new method of manufacturing did not represent a technical improvement, as some present-day researchers believe (e.g., Foster 1960:101; Katz 1977:124-25). Some kinds of vessels, such as small bowls and pitchers, could be made faster with the wheel, however, bigger forms such as large cazuelas or ollas were difficult to make by that method that method. In addition, the connection between particular clay recipes, vessel shapes and methods of manufacture was the result of a vast pottery experience accumulated through generations. Potters could not simply replace the ancient forming method in favor of the wheel without also incorporating important changes in the clay and morphology of the vessels. In addition, the method of forming vessels involved motor habits mastered and internalized by frequent repetition, and also knowledge of the sequence of execution. This knowledge was transmitted across generations but it was a knowledge implicitly remembered. That is, potters might not consciously recognize that they were remembering and transmitting all the bodily skills required for making a pot in the adequate way. This likely resulted in the fact that no explicit efforts were made to modify those abilities. In addition, this process was normally not visible in the final products, and consequently users or other potters did not modify it. Furthermore, this was one of the most difficult parts of the process of manufacturing and required knowledge. In family-based workshops, it was acquired from parents or other older relatives, and as a form of respect to them, this knowledge was maintained. Probably for all these reasons the method of forming was very conservative.

In the early colonial valley of Mexico some lead glazed vessels were made with the wheel while others were made by mold. This can be recognized in the vessels themselves; in particular in common and simple examples for cooking and serving as their surface still has some 


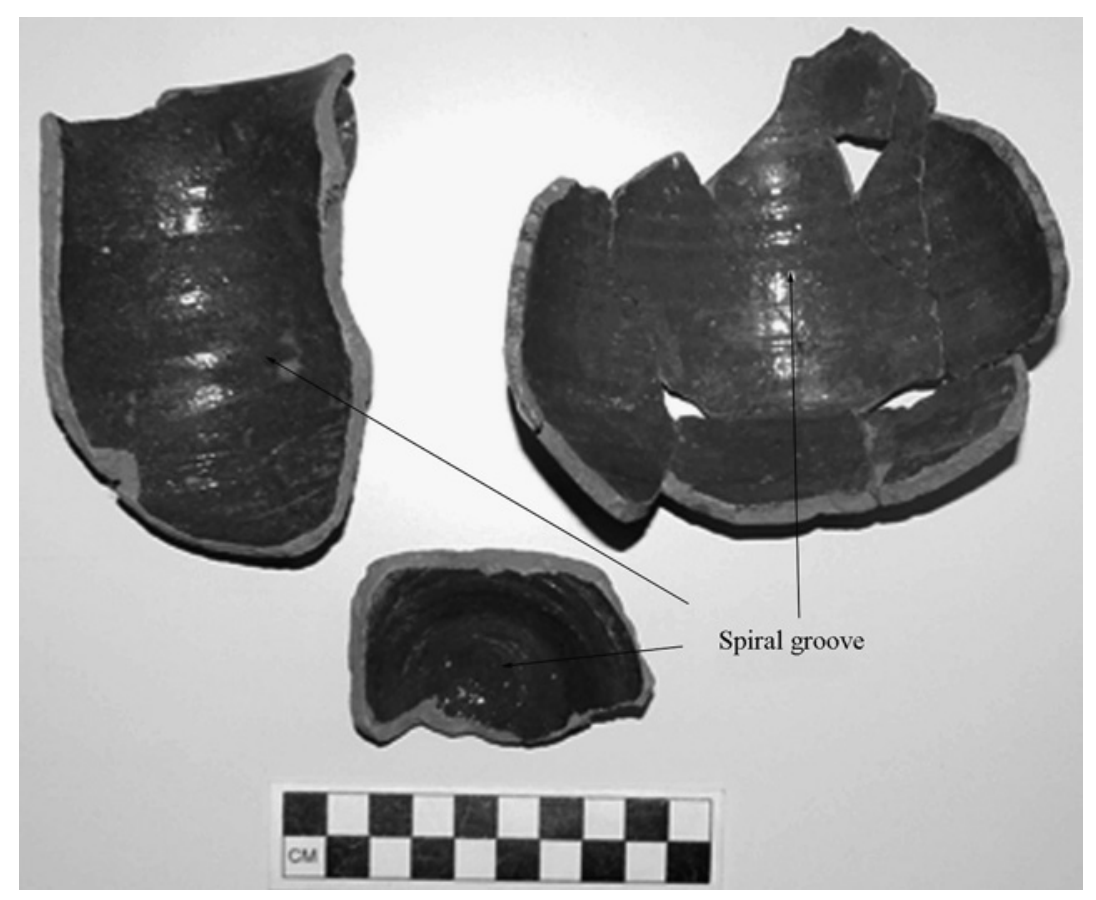

Figure 12. Fragments of vessels made by wheel with compression rings on the interior of the walls.

visible marks of the process of forming (fine objects with thick layers of painting or glazing have in contrast covered those marks). Thus, ollas, bowls and vases formed with the wheel show a spiral groove across the interior of the base and compression rings on the interior of the walls which are unlikely to be confused with other surface markings (Rye 1981:75) (Figure 12). In contrast, the same kind of vessels made by mold present smoothing marks that tend to be concentric but may also be irregular, which are different to the ridges left by the wheel. Ollas also had juncture marks of the mold in the middle of the body and sometimes in the connection between body and neck.

In general vessels with shapes of Spanish origin, such as candle holders, basins (basines), oil jars (botijas), plates or high narrow drug vases (albarelos), were made with the wheel. In contrast, vessels with shapes of indigenous origin, such as ollas, cazuelas and bowls, were made with molds. This may suggest that these two groups of vessels were made in different workshops. It seems that after the conquest 
indigenous-style workshops continued using the same methods of manufacture for producing the known repertoire of vessels. At the same time, Spanish-style workshops for manufacturing Spanish-style vessels used the wheel. Certainly there were exceptions. In the collections of the Departamento de Colecciones Arqueológicas there are a few scarce examples of Spanish-style vessel shapes, in particular candle holders and plates, with marks of mold and not of the wheel. The difficulty for recognizing fine temporal distinctions in early colonial contexts in the valley does not permit us to explore in more detail how the dynamics of manufacture of lead glazed vessels all through that period were.

Majolica wares were all made by wheel. Thus as a rule, vessels with Spanish-style shapes were made by wheel. A possible exception is a serving ware present during the sixteenth century in Mexico City decorated with white slip covered with lead glaze, which has the appearance of Majolica although its glaze is not blended with tin. Archeologists call them Indígena Ware (Lister and Lister 1978:19). Observation suggests that these vessels were made with the mold as the typical marks of the wheel are not detectable. However, as slip and glaze have covered large parts of the vessels' surface, it is still necessary to conduct microscopic analysis to confirm this hypothesis. The vessels show Spanish-style shapes, in particular plates and small bowls, but are decorated with motifs both of Spanish and indigenous origin. Chemical analysis of the clay suggests that they were made in Michoacán (Fournier et al. 2007).

\section{(c) Vessel surface finishing}

After the conquest the surface finishing and decoration of indigenousstyle vessels manifested notorious changes. We can recognize two major trends. On the one side, serving vessels evidence a great impulse of creativity and innovation. Potters modified parts of the surface finishing and decoration that existed before the conquest, and also experimented with new techniques. This was in particular the case of the Red Wares in which new styles and motifs of decoration are observed. Many of them were not new in pre-Hispanic Mesoamerica but were used for the first time in this kind of vessel. At the same time, the manufacture of other decorated serving wares decreased and was a bit simplified, such as the Black-on-Orange and the polychrome vessels. On the other side, a second trend was that the surface finishing of 


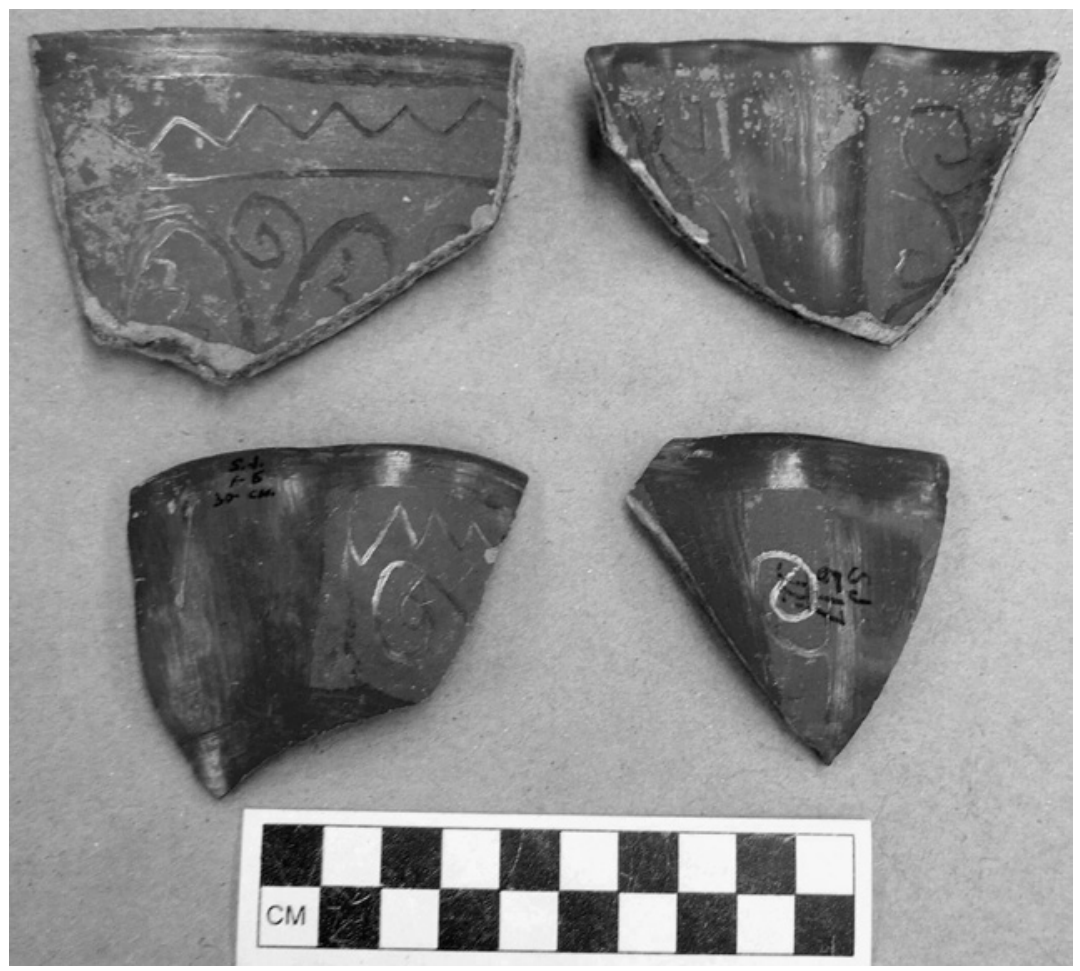

Figure 13. Fragments of early colonial Red Wares from the valley of Mexico.

cooking vessels and other utilitarian artifacts was simplified while a new technique-the lead glaze-became quite popular.

Potters dedicated to the manufacture of Red Wares had notorious creative impulses during early colonial times. They innovated and experimented with surface finishing, decoration and shapes (Figure 13). At present we have a relative good knowledge of the colonial expression of these kinds of vessels as they are common in many contexts from that time in the valley of Mexico and neighboring regions (see Cervantes et al. 2007; Charlton 1996; Charlton et al. 1987; Fournier 1996; Plunket et al. 1994). Also archeological explorations in Tlatelolco, the largest market in Tenochtitlan/Mexico City, obtained a large sample of colonial Red Wares and they have been studied and published (Charlton et al. 1995; Fournier 1997). These ceramics evidence a variety of new ways of surface finishing and decoration after the conquest. For example, the red slip began to be decorated with differential polishing and zonal painting applied on specific zones of the 
vessel while some parts were only smoothed (Charlton et al. 1995:143). This method of decoration was used in pre-Hispanic times but it became more complex and frequent after the conquest. Also decoration using stamping and incrustations was new (Charlton et al. 1995:143-44; Fairbanks 1966). Although these decorative techniques were well known in pre-Hispanic Mesoamerica, they were as a rule not used in Red Wares. In addition, colonial red vessels were longer burnished, and consequently had a more lustrous appearance. Also colonial wares were burnished in different directions while pre-Hispanic wares were more regularly and horizontally burnished. This implies that not only did new decorations emerge but also new methods of working. There were also innovations in decorative motifs; that is, colonial red vessels with black decoration had thicker lines than their pre-Hispanic antecedents. Also colonial vessels incorporated well-known Mesoamerican motifs not used before in this kind of ceramics, as well as elements inspired by the European decorative tradition. The black painting itself changed. After the conquest shimmering mineral black painting, similar to graphite, became more frequent. Further, there were modifications in the distribution of decoration in the vessel's space. In pre-Hispanic Red Wares decoration was placed on interior and exterior sides while in colonial times it was more frequent on the interior, even when vessels had closed shapes such as hemispherical bowls. Also red vessels with black and white decoration became less frequent after the conquest. It seems that the fugitive matte white painting was no longer preferred by potters and users.

In contrast to the great creativity associated to Red Wares, other decorated serving vessels manifested less innovation in early colonial times. Also their production was reduced, and ultimately disappeared roughly a hundred years after the conquest (see Charlton et al. 2005; Garraty 2006b:368). The most characteristic Late Aztec decorated wares, the Black-on-Orange vessels, continued after the conquest. However it seems that at least in some parts of the valley potters modified the method of finishing their surface. Charlton and colleagues (2007:440) observed in rural settlements in Otumba that after the conquest more vessels were finished with a reddish slip instead as with burnishing. This modification seems to be a simplification in the manufacturing process as burnishing is more time-consuming than slip application. In addition, Black-on-Orange vessels incorporated new decorative motifs (Figure 14). Some of them were not new, but were in the past exclusive of other kinds of vessels, such as the Red Wares. 

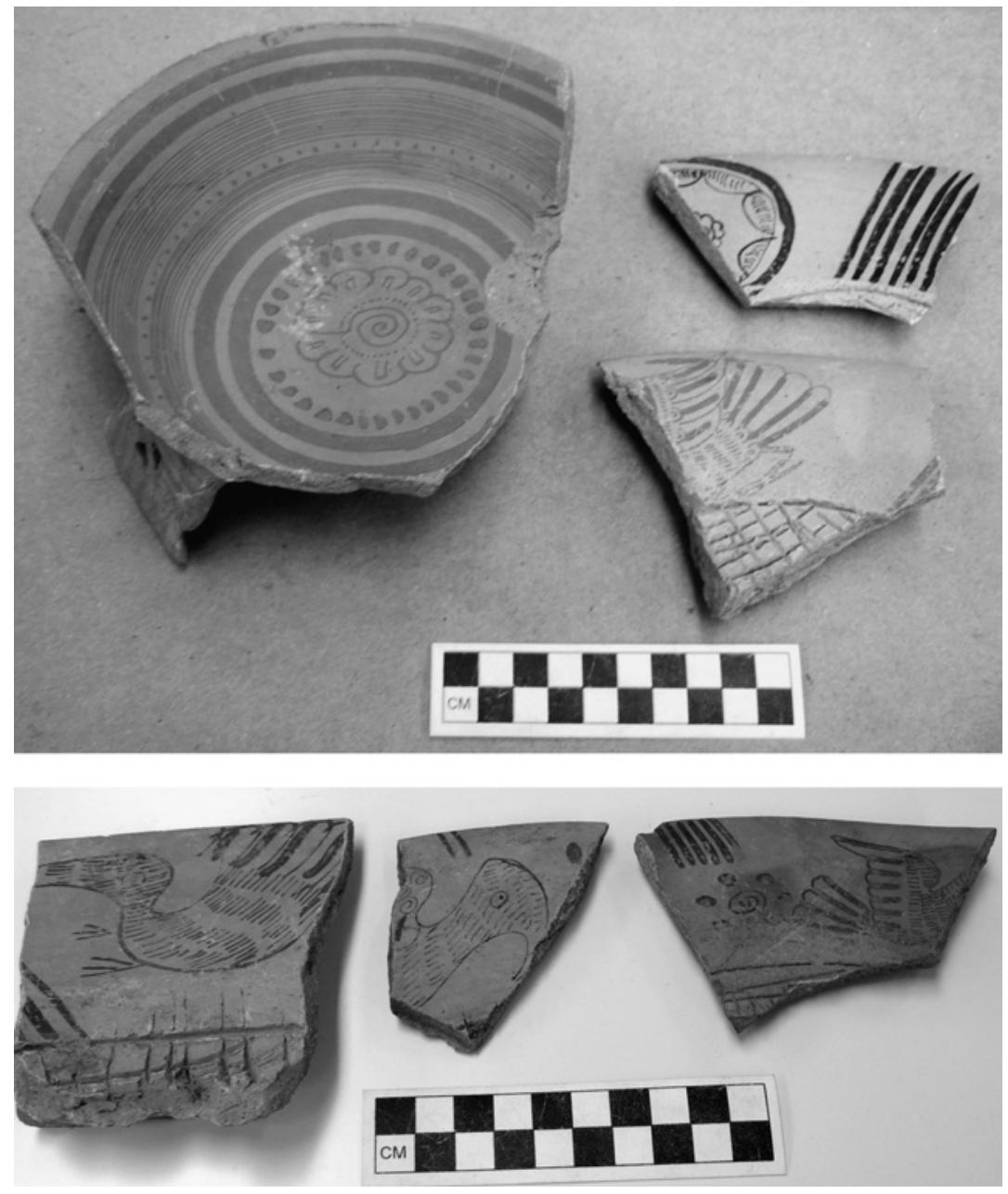

Figure 14. Fragments of early colonial Black-on-Orange wares from the valley of Mexico.
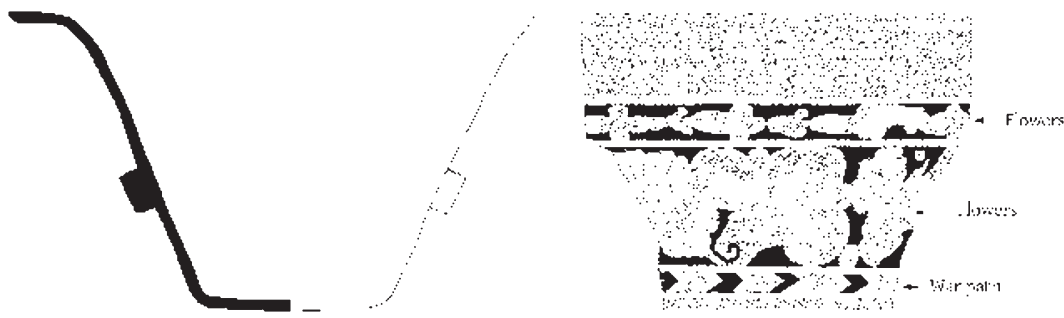

Figure 15. Early colonial fine polychrome vessel with pictographic decoration from Cholula. 
Other motifs were apparently inspired by the decorative traditions introduced by the Spaniards.

Also the fine polychrome wares from Cholula changed after the conquest and disappeared at the end of the early colonial period (Lind 1994:81). Although the few extant colonial examples of these ceramics do not permit detailed insights into the modification of their decoration, we can recognize a few trends. Motifs clearly associated to preHispanic religion and ritual practices seem to disappear in colonial times. Decoration incorporated some motifs and styles of representation of the European tradition (Figure 15). At the same time, the high quality and gloss of the surface characteristic of pre-Hispanic vessels was maintained.

Cooking vessels such as ollas, cazuelas and comales continued to be made after the conquest, however, their surface finishing was a little modified. Potters increased the application of a reddish slip. At the same time they reduced burnishing, and the consequence was that vessels look more matte. This was evidenced both in rural and urban contexts of the valley, and for this reason, some scholars have suggested that it implied deterioration of the pottery tradition (Charlton et al. 2007:436, 437). Nevertheless, when the whole panorama of colonial pottery is considered, it seems that these changes were related to the introduction of lead glazing. The glaze technique consisted of the application of a mixture of lead oxide, silicate and clay to the surface of a fired vessel (Charlton et al. 2007:485-486). After that, the vessel was fired again at high temperature; and the glaze material melted and fused to the surface, obtaining a physical structure similar to glass (Rye 1981:44). The result was a glossy vessel with brownish or greenish glaze.

The application of lead glaze for decorating vessels was an early Spanish introduction. It seems that this technique had a good acceptance by native potters and was established in indigenous-workshops by the second part of the sixteenth century. Sahagún (1961, X: 839) in his description of potters and the pottery craft mentioned that they made a variety of pre-Hispanic wares but also glazed vessels. This reference could date the establishment of this technique among native potters between 1547 and 1569, when the production of the Floretine Codex is estimated (D'Olwer and Cline 1973:193), although it could occur earlier. Unfortunately the morphology and archaeological context of indigenous-style glazed vessels do not provide more chronological detail. For example, in several places of the valley of Mexico 


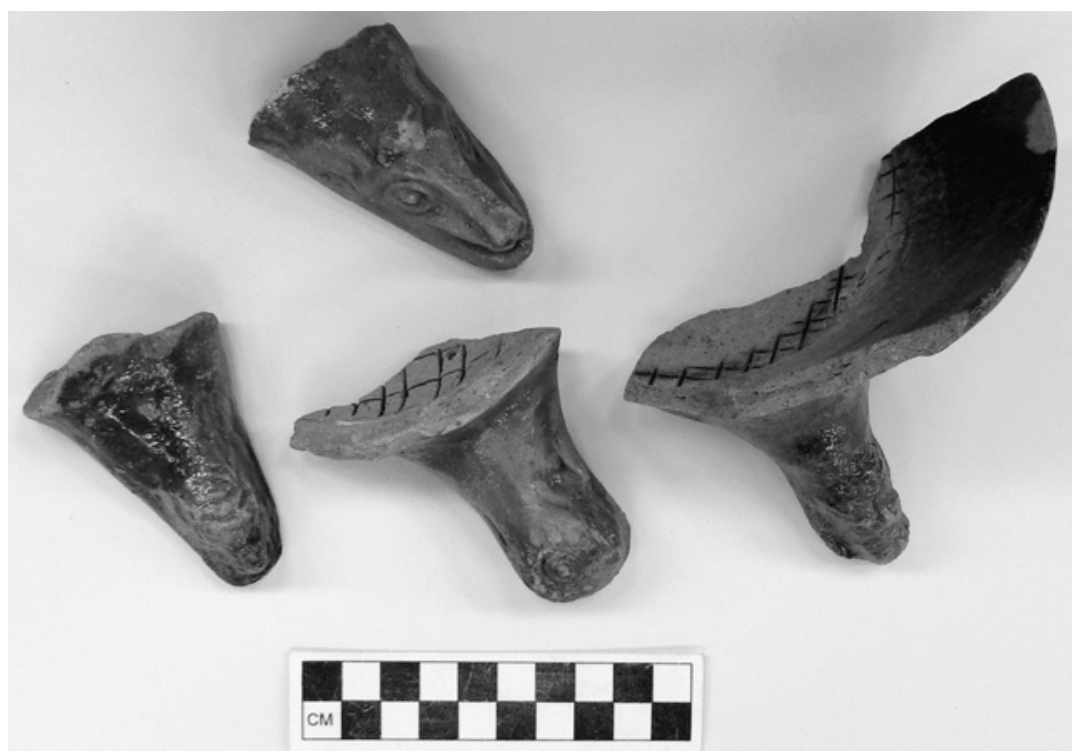

Figure 16. Fragments of early colonial molcajetes with lead glaze from the valley of Mexico.

have been found typical pre-Hispanic vessels with lead glaze, specifically molcajetes (Figure 16). These objects are dated for the early colonial period (AD 1521-1620), according to their morphology and context (Charlton et al. 2007:486); however we are not yet able to date them with more precision. Molcajetes often present a brown glaze with light greenish spots or even a glaze almost entirely light green. This kind of greenish coloration suggests that vessels were fairly over fired and that the kiln did not have enough air (Rye 1981:110-119); both aspects suggest that potters were in the process of experimenting and learning this technique. Molcajetes were clearly for indigenous users. Their function as grinders for chilli sauces was pre-Hispanic; also their shape and decoration were distinctively pre-Hispanic. In addition, other kinds of indigenous-style vessels were also glazed, like ollas and cazuelas.

Lead glaze as surface finishing required different types of effort and energy than the typical pre-Hispanic surface treatments. These vessels did not require finishing the surface with detailed burnishing, as the glaze covered most of the previous process of finishing. However these vessels required two firings and higher temperatures, and therefore a larger amount of fuel. Even with the higher efforts this involved, 
indigenous-style workshops implemented this technique, as is evidenced by the presence of glazed vessels with indigenous-style forming methods and morphology. Although the glaze notably altered the appearance of these vessels, it was relatively easy to implement without modifying other parts of the process of manufacture (with the exception of firing). The fact that this technique was not only implemented in serving wares that are normally those in which potters' influences are reflected, but also in cooking wares, shows that lead glaze had an important impact in the indigenous pottery. This was not exceptional, however; Mesoamerican potters had always been open to new forms of surface finishing and decoration as the variety of preHispanic vessel repertoires in different epochs and regions show.

In contrast, the Majolica technique was apparently not adopted in indigenous-style workshops. It consisted in the application on a fired vessel of a mixture of tin, lead and silicate, and decorative motifs painted with metallic oxides; after a second firing the vessel acquired a white milky glaze and decorative patterns in various colors (see Lister and Lister 1982). In late colonial Mexico the guild regulations permitted the manufacture of fine grade Majolica, which had a higher concentration of tin in the glaze and therefore had a whiter appearance and was also more carefully fired, and the common grade Majolica, with less tin and less care during firing (see regulations in López Cervantes 1976:15). Some specialists consider Indígena Ware (vessels with white matte slip covered by lead glaze) as indigenous imitations of Majolica ware (Charlton et al. 2007:470-71; Lister and Lister 1978:21). However we do not yet have enough data to confirm that it was made by indigenous potters or in indigenous-style workshops.

In brief, potters implemented many changes in vessels' surface finishing after the conquest. The new colonial culture apparently influenced to a large extent the decorative preferences of potters and consumers. Red Wares became the favorite among indigenous-style ceramics, not only in the valley but also in neighboring places such as Cholula and Cuernavaca (Charlton et al. 1995:150; Fairbanks 1966; Müller 1973:98; Plunket et al. 1994). It also seems that they were preferred by various sectors of colonial society, as they have been found, for example, in Tlatelolco, which remained an indigenous sector of Mexico City in colonial times (Fournier 1996), in houses in La Traza in Mexico City (Rodríguez Alegría 2005), in the palace of Cortés in Cuernavaca (Charlton et al. 1995:150) and in the Franciscan convent of San Gabriel in Cholula (Plunket et al. 1994). The colonial popularity 
of this ware contrasts with the decrease of Black-on-Orange wares, as well as with the reduction of polychrome vessels; those which were in pre-Hispanic times highly appreciated. Both wares disappeared around the end of the early colonial period (Charlton et al. 2007:439442; Lind 1994:81). However we cannot yet date these events with more precision as we do not have enough temporal detail for contexts of the late sixteenth and seventeenth centuries. In my opinion the disappearance of these wares was related to the introduction of the glazing technique.

\section{(d) Firing}

The methods for firing indigenous-style vessels seem to be maintained after the conquest. Although pre- and post-conquest evidences for pottery workshops and firing technology are scarce, we know that in Tula, potters were firing their vessels in two-chamber updraft kilns, pit kilns and open firing at least from the tenth to the twelfth centuries (Hernández et al. 1999). Similar kilns were also employed in central Veracruz during the Classic period (Pool 1997). For other regions of central Mexico we do not have comparable data yet, so we do not know how extended the use of pottery kilns in late pre-Hispanic times was. Nevertheless, it is probable that two-chamber kilns such as those of Tula were also used in other pottery-making towns. These facilities were clearly visible in the workshop and their implementation had evident effects on the production, such as the possibility to achieve temperatures in the range of 1000 to $1300^{\circ} \mathrm{C}$, the control of the atmosphere of firing and the rate of temperature rise (Rye 1981:98). Therefore, potters' neighbors, clients and visitants could easily observe this kind of kiln, recognize its value, understand its function and reproduce it in other workshops, even in far places considering that the interregional exchange of ceramics and ideas was quite extensive in late pre-Hispanic times. Similar kilns were used at that time in Spain and had a large tradition in the old world. Greek, Roman and other Mediterranean pottery, and Arabic glazed ware were fired in updraft kilns (Rye 1981:100).

Early colonial ceramic remains from the valley of Mexico and neighboring regions suggest that indigenous potters continued firing their vessels in similar conditions after the conquest. That is, early colonial Red Wares were still fired with a relatively low temperature as was the case in earlier times. Evidence for this is the high frequency of 
vessel fragments with dark clay cores and firing clouds. Orange wares, however, seem to be fired at fairly lower temperatures than in preHispanic times. This can be recognized in that Black-on-Orange serving vessels were less hard and had less metallic sound than before, and that orange cooking wares often had darker surfaces and clay cores (Charlton et al. 2007:440, 436). According to Charlton and colleagues (2007:440,436), the increase in the use of red slip for these vessels during the early colonial period might be related to the changes in vessel appearance as a consequence of lower firing temperatures. This gives the impression that the process of manufacture of orange wares was to some extent simplified after the conquest. In my opinion, one of the reasons might be the predilection for lead glaze.

Lead glazed vessels had to be fired twice and the second firing required higher temperatures. Vitrification can begin at about $700^{\circ} \mathrm{C}$, but generally does not become extensive below $900-950^{\circ} \mathrm{C}$ (Rye 1981:108). Such a temperature could be well reached in kilns such as the two-chamber updraft kilns from Tula. This kind of facility was more convenient to fire glazed wares than open fires as it could reach and maintain higher temperatures (Rye 1981:98). However archaeological remains of colonial kilns are to my knowledge very scarce (e.g., Gámez 2003:237), so we cannot recognize if the expansion of lead glazed ware production in central Mexico was accompanied by the expansion of this kind of kiln. Certainly an effect of glaze ware manufacturing was the environmental impact. These ceramics required more fuel than non-glazed indigenous-style ceramics as they were fired twice.

Majolica wares were also fired twice. An important aspect of that process was the separation of vessels in the firebox in order to avoid that they stuck and melted together. Potters used for this purpose cockspurs with three support struts to separate common Majolica, while fine grade Majolica was placed in saggars, ceramic boxes in which triangular pegs were used to hang the pieces upright (Lister and Lister 1978:12). Among the remains of a colonial Majolica workshop excavated in Mexico City all these implements were found (Gámez 2003:237). The lack of scars left by pegs or saggars or by the separation of pieces melted together was one of the main criteria to distinguish between fine and common Majolica (see Ordenanzas in López Cervantes 1976:15). It seems that in the case of lead glazed ceramics such firing imperfections were not so relevant. Lead glazed vessels, both of indigenous-style as well as Spanish-style often had firing scars. 


\section{(e) Decoration}

After the conquest the form and content of decoration on ceramics, and even the function of decoration itself had changes. Potters embellished their vessels with new motifs and new stylistic patterns, but also incorporated in certain wares well-known elements and designs that in the past were exclusive of other wares. This was in part a result of the new ideas produced by the encounter between indigenous and Spanish culture. Possibly this was also a consequence of the end of the centralized market system during the Aztec empire. That is, Hodge and Minc (1990:426-433) have identified that ceramics of the valley of Mexico in the Late Aztec period -in imperial times- had less variability in comparison to the Early Aztec period. They propose that this was because goods were distributed through a geographically widespread exchange system, creating a higher degree of similarity in artifacts through the region. After the conquest the distribution of ceramics across the valley is more similar to that of the Early Aztec period (Garraty 2006a:222), when potters and consumers have access to several independent exchange centers as the higher variability of ceramics suggests (Hodge and Minc 1990:426-433).

The various decorated wares for serving had different dynamics of change during early colonial times. Black-on-Orange vessels incorporated a variety of new decorative motifs. In contrast, Red Wares do not show much innovation in motifs, rather than in decorative techniques. Besides, in the fine polychrome ceramics some of the earlier pictographic motifs with clear religions connotations (see Hernández 2005) disappeared. My impression is that meaningful decorative elements were less frequent, which suggests that painted ceramics were less used as media of visual communication in the early colonial society. This remains impression however; as the extant collections of late pre-Hispanic and early colonial polychrome vessels from central Mexico cannot be well compared. That is, fine polychrome vessels from undisputed colonial contexts are very scarce. Also many of the known examples are identified as colonial only due to morphology (they present forms typical of other colonial vessels such as small bowls with basal rings).

Early colonial Black-on-Orange serving wares manifested several changes. The typical Late Aztec bands of lines and motifs on vessel walls were simplified, lines became thicker and new configurations of elements appeared (Whalen and Parsons 1982:450). Also colonial 

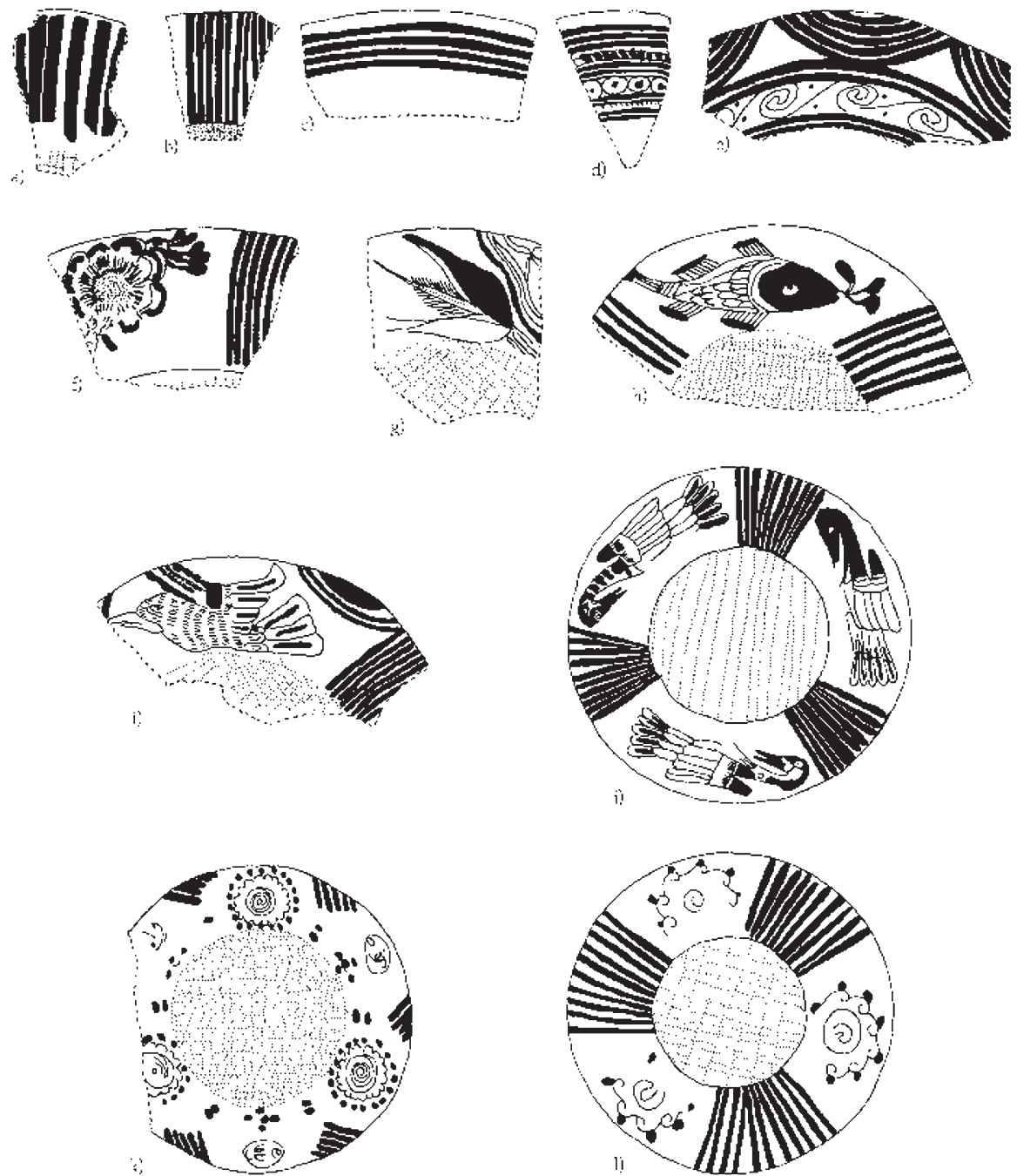

Figure 17. Patterns of decoration on early colonial Black-on-Orange wares from the valley of Mexico: (a, b, c, d) molcajetes and tripod bowls (based on Charlton et al. 2007: Fig. 12) (e, f, g, k) molcajetes and tripod bowls (based on Charlton et al. 2007:Fig13) and (h, i, j, l) molcajetes (based on Charlton et al. 2007: Fig. 14). 
Black-on-Orange vessels were often decorated with groups of vertical lines on their interior walls, a composition exclusive of Red Wares in pre-Hispanic times (see Blanton and Parsons 1971:299). In addition, colonial vessels were often decorated with figurative motifs (Figure 17). These motifs were often iconic, such as birds, fishes, flowers and leaves, and had a new style of representation (see Charlton et al. 2007:Figs. 13-17; Vega 1975:60, 61). That is, flowers were often painted in profile (pre-Hispanic flowers were often depicted frontal) and birds were fully represented (pre-Hispanic birds only the head). Also, these images had a few indications of depth. Some scholars have suggested that they were derived from the European decorative tradition (Noguera 1934:272; Whalen and Parsons 1982: 450). However, flowers and birds were typical signs of the central Mexican system of visual representation during late pre-Hispanic times. Leaves and fishes were also known images although they were not often depicted (see Hernández 2005). Thus the innovation was that these motifs became more frequent after the conquest and their style was a bit modified. This might be inspired by the colonial world as these elements were also common in Spanish decorative traditions (see Lister and Lister 1987). Not all signs on orange vessels were new, however; potters still painted some motifs present in this ware since the Early Aztec period such as stepped frets, precious stones and water volutes (see Charlton et al. 2007:Figs. 13, 15, 17). All these modifications of the decoration on orange wares have been identified in both urban and rural ceramics (Charlton et al. 2007:439-441), which suggests the new stylistic trends were widespread in the valley of Mexico.

Red Wares incorporated new painted motifs but the most visible innovations were on the treatment of the surface. It seems that potters preferred to embellish those vessels with red slip and a variety of surface finishing such as modelling, differential polishing (see Figure 13), stamping or incrustations, rather than with painted decoration. Nevertheless, on occasion vessels were also painted with black motifs of pre-Hispanic origin, like circles, stepped frets, cut snails and spirals (Charlton et al. 1995:144-148). Although these elements were wellknown in pre-Hispanic times, they were rarely present in Late Aztec Red Wares. This suggests a easing of stylistic conventions in ceramics after the conquest. Also colonial Red Wares included a few new motifs, like flowers and leaves, painted in similar style as on Black-on-Orange wares, that is, in profile, with full body and with some indications of depth (Figure 18). In addition, in some pieces were painted bands of 


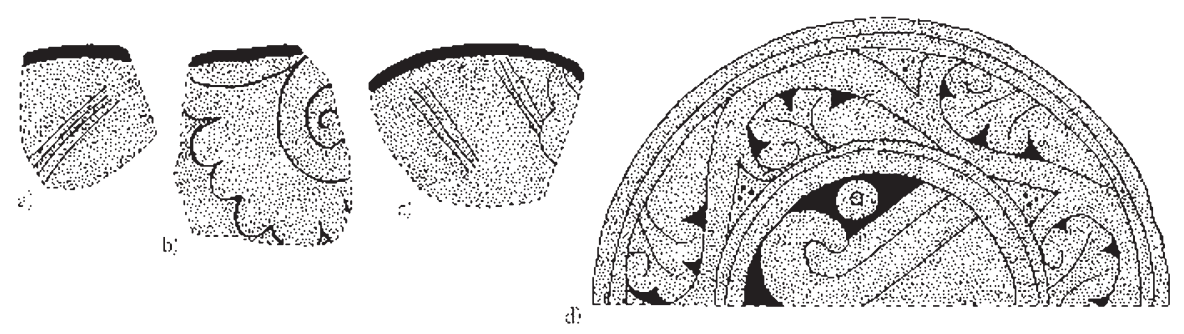

Figure 18. Patterns of decoration on early colonial Red Wares from the valley of Mexico: (a, b) bowls with flared walls (based on Charlton et al. 1995: Fig. 6) (c) bowl with upright walls (based on Charlton et al. 1995: Fig. 5) (d) plate with interior decoration (based on Charlton et al. 1995: Fig. 8).

curvilinear motifs relatively similar to designs painted on the so-called Indigena Wares (see Charlton et al. 2007: Fig.49), the vessels with white slip and lead glaze that might be imitations of Majolica. The decoration on those red vessels, consisting of patterns of volutes and other curvilinear elements, had as well some resemblance to the decoration of early colonial Majolica wares from Mexico and Europe (see Lister and Lister 1987). The style of these new ceramics was probably a source of ideas for indigenous potters.

The fine and colorful vessels decorated with pictographic motifs also saw changes after the conquest. Although these ceramics are scarce in collections from early colonial contexts in the valley of Mexico and the extant examples are highly fragmented, we can recognize a few details. In vessel sherds found in colonial deposits at the Templo Mayor, and on objects without detailed provenance but with morphology typical of the early colonial period, we observe that decoration became more mundane. That is, colonial vessels were no longer painted with signs of evident religious and ritual associations. For example, agave thorns and bone awls, well-known pre-Hispanic sacrificial instruments and frequently depicted on earlier vessels, no longer appear on colonial period ones. Also other ritual implements or images and symbols of gods are absent. In contrast, flowers and birds became frequent (see Figure 15). Although these motifs were also part of the late pre-Hispanic pictographic corpus (see Hernández 2005) and had important meanings in ancient religious and ritual contexts (see Anders and Jansen 1993:120; Dibble 1971:324; Nowotny 1961:38; Seler 1963, I:47, 156), they were apparently less obvious for outsiders, and also had other connotations in the new colonial society. On other early colonial vessels these two signs were frequent as well. In addition, 


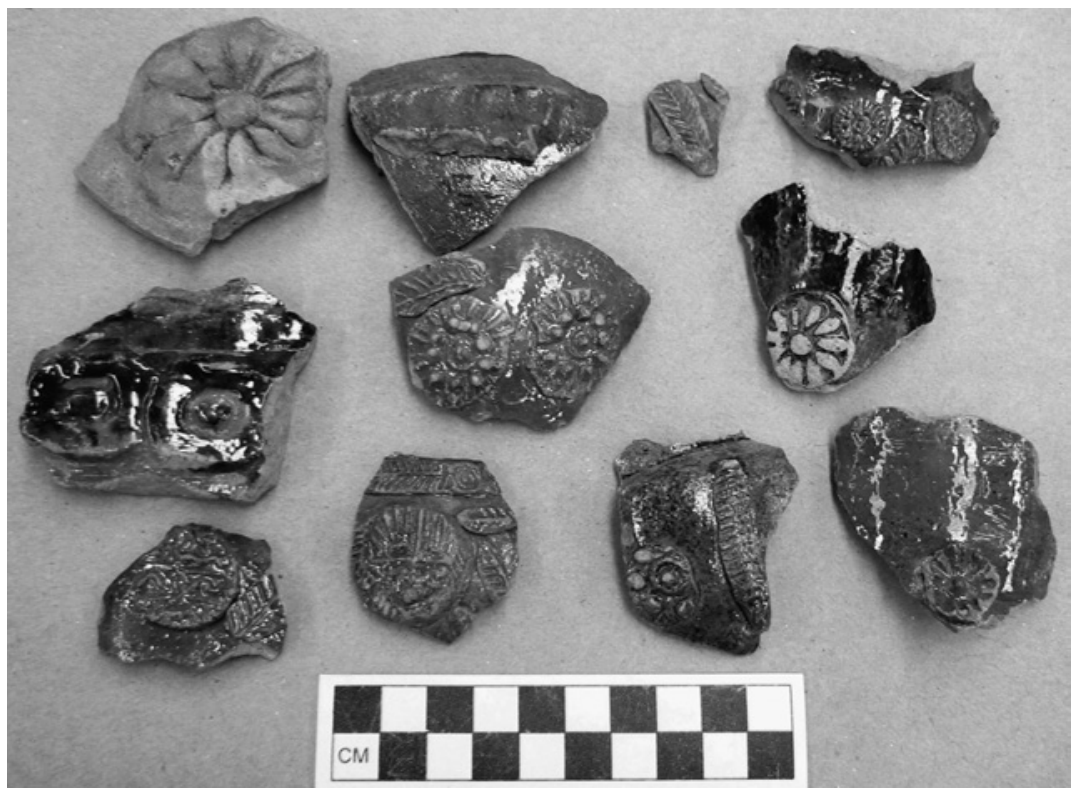

Figure 19. Patterns of decoration on early colonial lead glazed wares from the valley of Mexico.

the pictography on colonial polychrome wares was simpler and less varied. The fact that the thematic of pictographic short texts on vessels became more mundane and simple, suggests that after the conquest these vessels continued being special objects for special occasions, but their use in religious contexts disappeared. It also seems that the function of these vessels as media for transmitting concepts associated to the context in which they were used became less important. These vessels disappeared at the end of the early colonial period (Lind 1994:81). Potters and users preferred other indigenous-style ceramics, in particular Red Wares, which were sometimes painted but their motifs neither constituted pictographic texts nor conveyed complex meanings. Thus, the disappearance of fine polychrome wares also implied the end of the tradition of ceramics as media for writing.

On occasion lead glazed vessels were decorated. The decoration consisted of stamping, incisions and applications made before the first firing; after that, the vessel was covered with glaze and fired for a second time (Figure 19). Motifs were simple, usually incised lines combined with flowers made through stamping or application. Some 

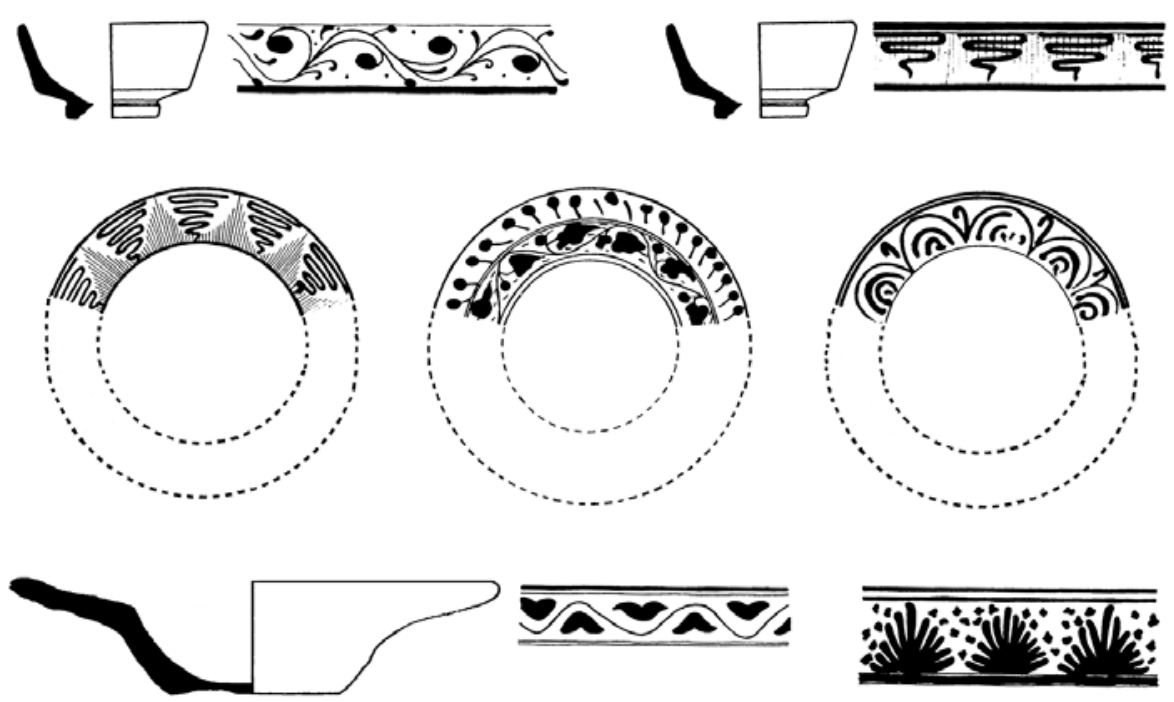

Figure 20. Patterns of decoration on early colonial Majolica wares from the valley of Mexico (based on Lister and Lister 1987: Fig. 85).

incised decorations were similar to patterns of lines characteristic of Late Aztec and early colonial Black-on-Orange vessels (see Charlton et al. 2007: Figs. 10, 12 and 13). This suggests once more the easing of stylistic conventions. Following the Spanish tradition (see Lister and Lister 1987), Majolica wares made in Mexico were decorated with bands of curvilinear and geometric motifs painted in several colors, mainly blue, yellow and orange (Figure 20). Compositions were similar to those of the Majolica produced at that time in workshops around Seville (see Charlton et al. 2007; Lister and Lister 1978, 1982, 1987). In Mexico City there were also a few decorated vessels imported from Spain, Italy and China (Charlton et al. 2007:481-485; Fournier 1990; Lister and Lister 1978). Potters specialized in indigenous-style vessels incorporated in the Red Wares a few elements of these new ceramics. However, indigenous and Spanish decorative traditions were maintained separate until the disappearance of Black-on-Orange wares and polychrome wares at the end of the early colonial period. Red Wares continued to be made in the late colonial period but their decoration was increasingly different to that of earlier times. Also other decorated 
wares of indigenous-style appeared in later times, for example, the Tonalá Ware, produced in that town close to Guadalajara after 1650 (Charlton and Katz 1979), and widely traded in central Mexico. The function of decoration in Majolica Wares was to embellish vessels, not to convey visual information in the form of short texts as was the case of polychrome wares decorated with pictography (Hernández 2005, 2010). In colonial ceramics of indigenous-style the function of decoration also became more focused on the aesthetic value rather than on conveying ritual or other important meanings.

\section{(f) Assembling vessel shapes}

After the conquest the indigenous vessels' repertoire had several modifications. Potters did not make drastic changes in the existing inventory of ceramics but were creative and innovative in formal details. For example, new kinds of supports appeared. Also a number of new shapes were incorporated. Many of these shapes were not really new, however. They were not manufactured in the last centuries before the conquest but they were present in earlier times. A few vessel shapes were in fact new; in particular in the inventory of Red Wares for serving. However in many cases those new shapes replaced shapes of similar function. Only very few vessels were created for new uses, like candeleros (candle holders). In addition, a few ritual vessel types continued to be made after the conquest although they were no longer manufactured by the end of the early colonial period.

In early colonial times common vessels for cooking, transporting and storing continued to be ollas, cazuelas and comales. Their basic shape was maintained as in pre-Hispanic times, although minor formal details were modified, such as the shape of the rim or the inclination of the walls (Charlton et al. 2007:436). Also fragments of these vessels suggest that their dimensions were maintained. The shape of ollas and cazuelas finished with burnishing was similar to those finished with lead glaze, suggesting that the main difference between glazed and non-glazed containers was decorative rather than functional. Vessels for serving food and drinks were comparatively more modified after the conquest. As in Late Aztec times, colonial Blackon-Orange wares and Red Wares had different vessel shapes and different stylistic developments. The basic shape repertoire of these wares 

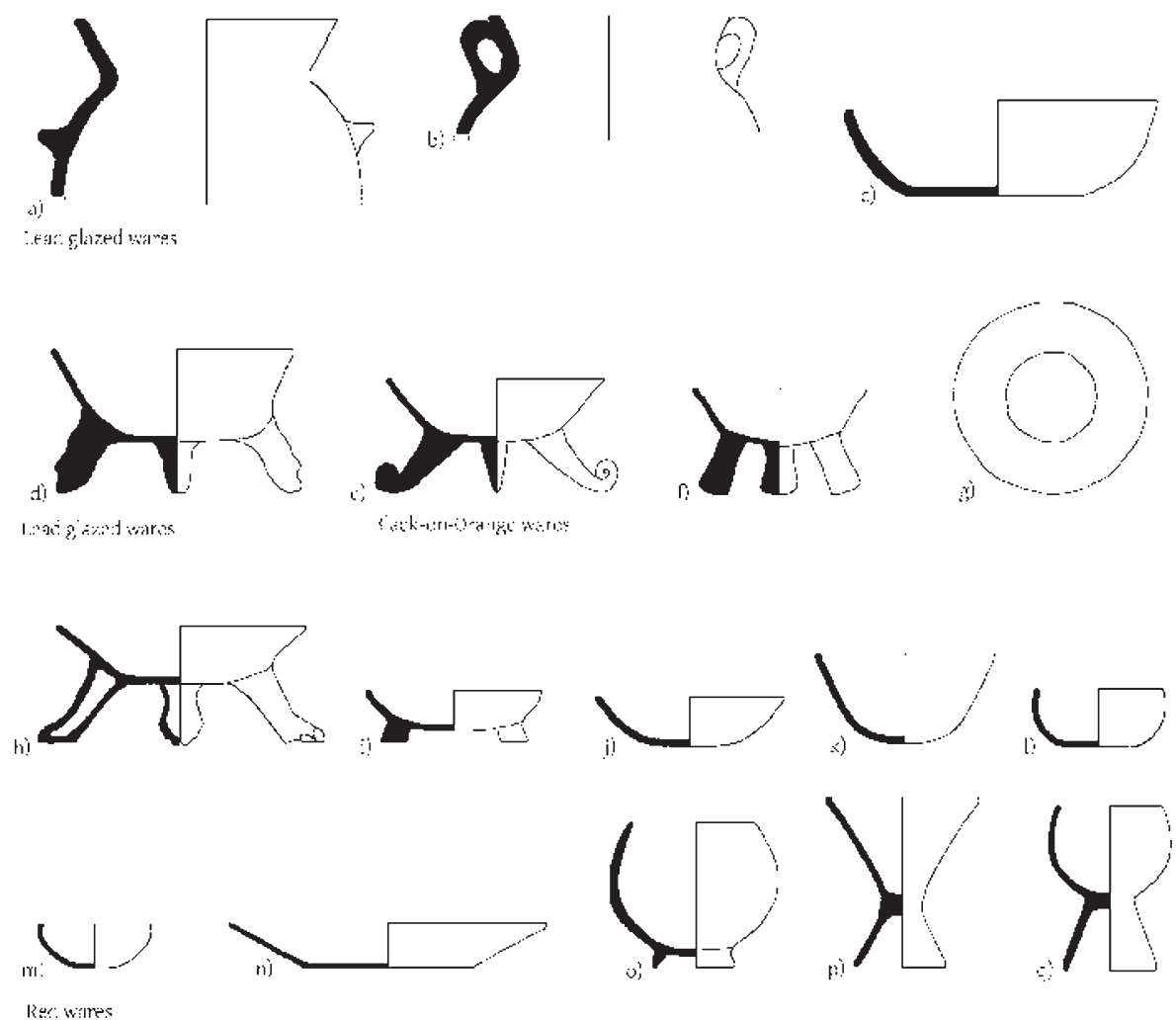

Figure 21. Shapes of early colonial serving vessels from the valley of Mexico: $(a, b)$ ollas (based on Charlton et al. 2007: Fig. 68) (c) hemispherical bowl (based on Charlton et al. 2007: Fig. 69) (d) tripod molcajete (based on Charlton et al. 2007: Fig. 66) (e, f) tripod bowls (based on Charlton et al. 2007: Fig. 15) (g) plate (h, i) tripod bowls (based on Charlton et al. 2007: Fig. 23 Rodríguez Alegría 2002: Fig. A.1) (j, k, l, m) bowls (n) plate (o, p, q) goblets (based on Charlton et al. 2007: Fig. 26; Rodríguez Alegría 2002: Fig. A.1).

continued but it seems that certain vessels shapes became more frequent (Figure 21).

Colonial Black-on-Orange wares maintained the typical pre-Hispanic shapes such as bowls with upright or flared walls, tripod bowls, dishes, plates, hemispherical bowls and pitchers (Charlton et al. 2007:436-452), although it seems that the popularity of certain vessels changed. Tripod molcajetes became more frequent than in earlier times; also the scarce hemispherical bowls with ring base became a bit more common (Charlton et al. 2007:438-439). The most evident 
innovation was related to the supports of tripod vessels. Supports in late pre-Hispanic bowls could be solid conical, hollow cylindrical or wide thin slabs (Blanton and Parsons 1971:304-309; Whalen and Parson 1982:441). After the conquest potters continued manufacturing these supports but also incorporated examples modeled in the form of butterfly antennae, eagle heads, duck heads, bird claws, deer and pig hoofs, lion claws or old men's faces (Charlton et al. 2007:442). Some of this variety of forms were used in pre-Hispanic times but were exclusive of other wares, such as the polychrome vessels with pictographic decoration used in Cholula (see Lind 1994:92). Other supports were inspired by colonial animals, like the pig hoofs and lion claws.

Early colonial Red Wares had notably more morphological innovations than Black-on-Orange wares. The Códice de los Alfareros de Cuauhtitlan offers excellent insights into the kinds of vessels made in 1564 and their nomenclature, at least in that town. The variety of vessel shapes illustrated in the codex is surprising as several of them are rarely represented in the archeological record (Figure 22). The document shows a list of vessels paid and not paid for by the alcalde mayor Juan Xuares de Peralta. Paid vessels were painted on the left side of the manuscript with red color while unpaid vessels were represented on the right side, but were only delineated and without color. This gives the impression that all pieces represented were Red Wares although this is not confirmed in the text. Even if they were not Red Wares, this document evidences the kind of vessels made at that time in one of the most important pottery towns of the valley of Mexico. The collection includes vessels with pre-Hispanic antecedent, Spanish antecedent and new shapes. Among the vessels with pre-colonial origin we recognize vessels named by them as molcaxetes, alcarrazas (jars with globular body, lateral handles and ring base), jarros (pitchers with ring base), and other shapes not named such as goblets with grooved walls and bowls with stamped designs on their bottom. Molcajetes were illustrated in association with a brief Spanish text indicating that they were molcaxetes para cacaos, and therefore they had a different function than the orange molcajetes for grinding sauces. All these vessels had pre-Hispanic antecedents, although in that particular form they were not common in Late Aztec Red Ware collections (see Cervantes and Fournier 1995; Cervantes et al. 2007). They look like elaborate versions of pre-Hispanic shapes; for example, the body is modeled with grooving (to form grooves on the leather-hard surface of the 

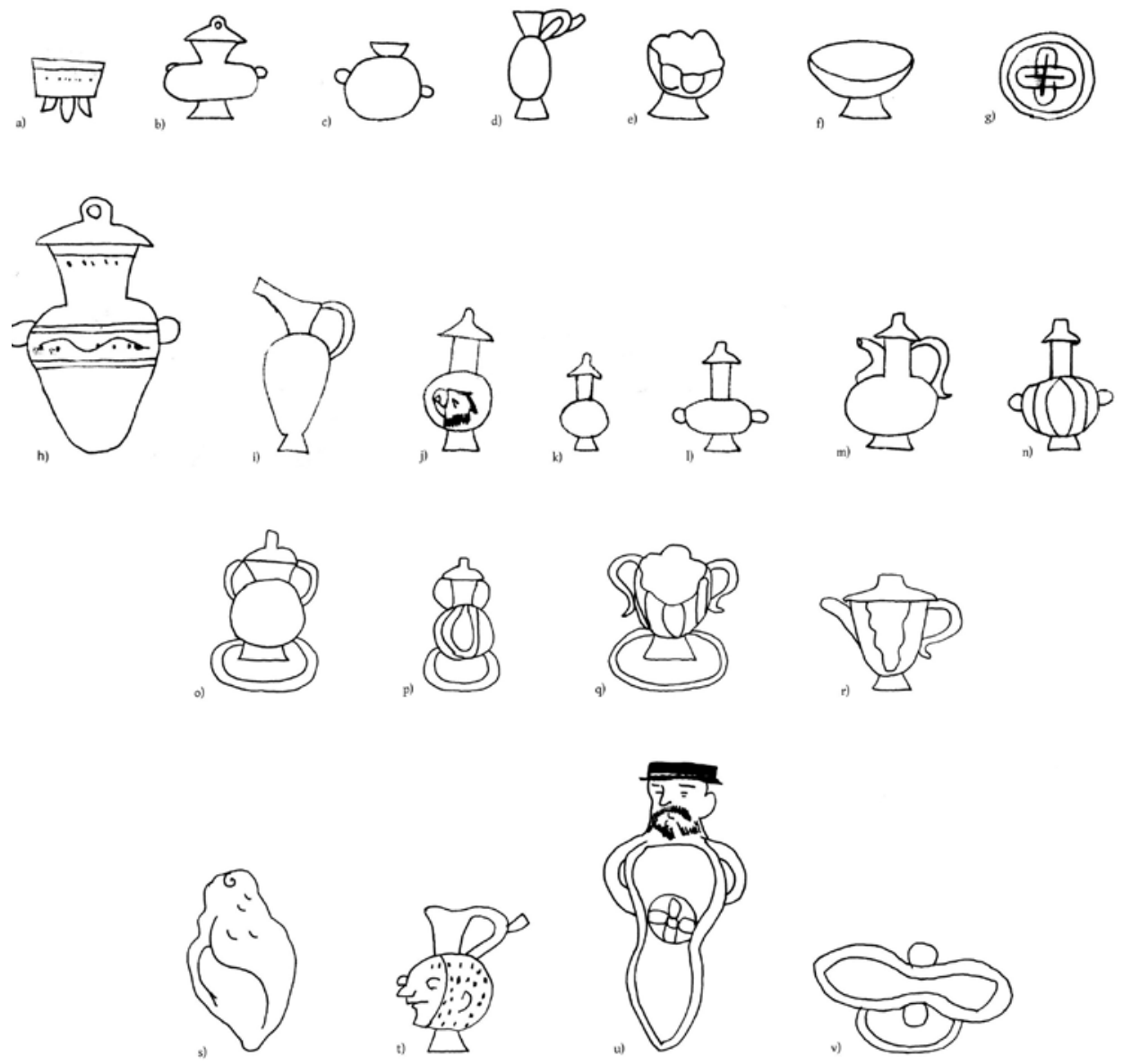

Figure 22. Vessel shapes depicted in the Códice de los Alfareros de Cuauhtitlan with the names given in the document: (a) molcaxete para cacaos (b, c) alcarrazas (d) jarro (e, f) goblets without name in the document (g) plate with incisions on the bottom without name in the document (h) tinaja (i) pitcher without name in the document (j) alcarraza (k) bottle with lid without name in the document (l) alcarraza $(\mathrm{m})$ jarro pichel $(\mathrm{n})$ alcarraza $(\mathrm{o}, \mathrm{p}, \mathrm{q})$ jarros $(\mathrm{r})$ sugar bowl without name in the document (s) jarro como caracol (t) jarro la hechura como negrito (u) jarro (kidney-shape bowl with an appendage on the rim modelled as a Spanish man and two handles) (v) jarro (kidney-shape bowl with a plate -or a pedestal base- and two handles on the rim viewed from the top). 
vessel), or a cover lid and a ring base are added. Other vessels illustrated had Spanish antecedents although they also had some Mesoamerican connections, even if they were not present in that form in late pre-Hispanic Red Ware collections. These vessels are named in the document as tinajas (amphorae with lids and small lateral handles), jarros picheles (pitchers with spout and handle, lid and ring base), alcarrazas (bottles with long neck, lid and small lateral handles decorated with an eagle), and other jarros (bowls with grooved walls, lateral handles and a small plate as if they were cups), and there are also other shapes not named (small pitchers with spout and handle, grooved body and ring base) that look like tee canes. There were also new shapes, such as jarros de caracoles (vessels modeled as snails), jarros de negritos (pitchers with long neck and ring base with body modeled like the face of a black man), and other unnamed bowls with composite kidney-like shape and an appendage on the rim modeled like the face of a Spanish bearded man with hut.

Some of the vessels in the codex were frequent in early colonial archeological contexts in the valley of Mexico, such as goblets, cups, pitchers and molcajetes (see Charlton et al. 2007; Fournier 1996:453). Others seem to be quite rare as is the case of the jarros de negritos and caracoles and those with the Spaniard face. The vessels with modeled faces were clearly a colonial innovation. Not only were the kind of personages represented new but the idea of modeling images on relatively common serving vessels was also new. Actually this form of embellishing vessels occurred in earlier times (some Teotihuacan style braziers had appendages with faces) but it was not common during the late pre-Hispanic period. This, however, corresponds well with the development of decoration on orange wares after the conquest. The painted decoration on these vessels became more iconic, that is, potters included more representations of animals and plants rather than linear and geometric patterns as in Late Aztec times.

All the vessels represented in the document as well as those found in archeological contexts were serving wares, some for individual consumption and some for the collective serving of beverages. In both cases the great morphological variety and creativity of early colonial Red Wares, which suggests that they became the favorite among indigenous-style ceramics is clearly evident. The illustrations of the codex suggest that already in the sixteenth century new shapes began to replace earlier red vessels of similar function; for example, it seems that cups replaced small drinking jars, or large jars with spout and 
handle replaced ollas for serving liquids. Vessels from archeological contexts also evidence this trend. Simple bowls with flaring walls and goblets became more frequent after the conquest, replacing simple hemispherical bowls (see Charlton et al. 1995:148; Fournier 1996:453). Also among new Red Wares registered were large plates, cups, small pitchers and sugar bowls; all of them suggest in their shape, and even in their function, colonial influences. For example, plates and cups were the most frequent forms in Majolica wares (e.g., Goggin 1968: 152-153; Rodríguez Alegría 2002, II:442). On occasion red plates and cups had the same shape as Majolica vessels, although in other cases proportions and dimensions were rather different.

It seems that colonial Red Wares responded to the habits and stylistic preferences of the new colonial society while colonial Black-onOrange wares remained more associated to the pre-Hispanic past. In both of them there were formal innovations but they were different. Black-on-Orange wares evidence a great creativity in supports while Red Wares seldom show these appendages. Tripod supports were clearly distinctive of the pre-Hispanic ceramic tradition while they were not used in Spanish ceramics (see Sánchez 1998). Thus their continuation in orange wares evidenced the connection with pre-Hispanic stylistic canons. In contrast, Red Wares included frequently ring bases. This ring for separating the base of the vessel from contact surfaces was common in Spanish-style ceramics (see Lister and Lister 1987; Sánchez 1998), although it was also known in pre-Hispanic Mesoamerica, in particular in Classic period Teotihuacan (see Rattray 2001). Red Wares also incorporated cover lids. In the same way as ring bases, vessel covers were common in Spanish-style ceramics although they were also known in Classic Teotihuacan (see Rattray 2001). In contrast, colonial Black-on-Orange wares as a rule did not have base rings or lids (see Charlton et al. 2007). Thus the incorporation of ring bases and lids in Red Wares evidenced the connection with Spanish stylistic canons. Many of the vessels illustrated in the codex of Cuauhtitlan also have ring bases and cover lids. In my opinion these attributes are represented as if they were distinctive elements at that time, as they appear, with clarity, in most of the vessels illustrated. In addition, Black-on-Orange and Red Wares had differences in morphological details but also in the assortment of vessels. Black-onOrange vessels were often tripod bowls and dishes for individual and collective serving of food (see Charlton et al. 2007; Whalen and Parsons 1982:450). In contrast, Red Wares had more variety of forms; 

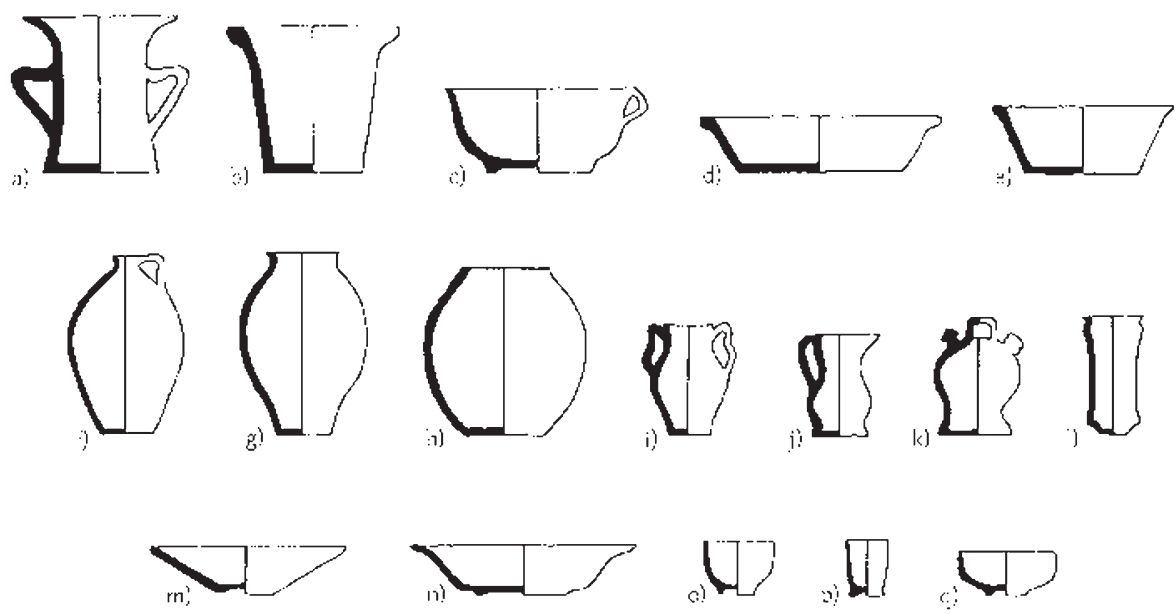

Figure 23. Vessel shapes made with the potter's wheel in the valley of Mexico: $(\mathrm{a}, \mathrm{b})$ bacín $(\mathrm{c})$ bacinilla $(\mathrm{d}, \mathrm{e})$ lebrillo $(\mathrm{f})$ cántaro $(\mathrm{g})$ tinaja $(\mathrm{h})$ orza $(\mathrm{i})$ jarra $(\mathrm{j})$ pitchel $(\mathrm{k})$ hidroceramo (botija) (l) albarelo $(\mathrm{m}, \mathrm{n})$ plato $(\mathrm{o})$ taza $(\mathrm{p})$ pocillo $(\mathrm{q})$ escudilla (based on Deagan 1987: Fig. 4.1).

some were for individual serving of food but also for individual drinking and for collective serving of food and drink (see Charlton et al. 1995:148, 2007:446; Fournier 1996:453). This suggests that Red Wares were made for a variety of uses and contexts, while Black-on-Orange wares became more restricted to certain contexts. The differences between these two wares were, however, not directly associated to urban vs. rural separation. Black-on-Orange and Red Wares have been found in both urban and rural locations (see Charlton et al. 2005:59; 2007: 446; Rodríguez Alegría 2003:315).

Indigenous-style vessels continued to be made with mold after the conquest. Orange and Red Wares for cooking and serving were made using this forming method. Not considering Majolica wares, vessels made with potter's wheel were lead glazed and had specific shapes (Figure 23). These were mainly plates with ring base, cups, pitchers, lebrillos (basins), bacines (basins with high walls), botijas (amphorae for olive oil), albarelos (high drug vases) and candle holders. All of them had Spanish antecedent and names taken from the Spanish vessels' repertoire (Lister and Lister 1987; Sánchez 1998). A few of them were clearly related to Spanish uses, such as the olive jars, which were lead glazed in the interior to avoid filtration (Goggin 1960). The rest 
could be associated to Spanish uses, such as the albarelos, which were medicine containers, or the lebrillos, which were chamber pots, but these uses were not exclusively Spanish customs. All these shapes were made with a Spanish-style forming method and did not incorporate Mesoamerican morphological details. This suggests that they were produced in Spanish-style workshops, and accordingly probably remained products for the Spanish colonial market.

A number of vessels for ritual uses continued to be made after the conquest. Charlton and colleagues (2007:455) report the presence of a few examples of long-handled censers in colonial urban contexts. They have also found a fragment of lead glazed censer in the rural area of Otumba. We do not know if these were used for indigenous rituals in domestic contexts or if they were incorporated into Christian ceremonies in churches. In any case, they were not frequent and they were not used in later times as they no longer appear in archeological contexts by the end of the early colonial period. Other objects with clear ritual use, such as large decorated braziers (e.g., Cervantes et al. 2007: Fig. 51), it seems that were not used in post-conquest contexts. Other pre-Hispanic ceramic ritual objects continued to be made after the conquest, nevertheless. They were not containers but figurines made of terracotta. These objects were typical of Mesoamerican life since at least the twelfth century $\mathrm{BC}$, and were mainly associated to domestic contexts (e.g., Cyphers 1993; Groove and Gillespie 1998; Marcus 1996). Briefly summarizing the work of several specialists (Charlton $e t$ al. 2007:455-458; Müller 1973:98; von Winning 1988), early colonial figurines were made following the pre-Hispanic manufacturing method but they began to represent Spanish persons or new animals, like sheep, donkeys or dogs. Persons distinctively showed Spanishstyle attire, such as dresses, huts and trousers. After the conquest the function of figurines changed, however. Later figurines were personages from crèche (Charlton et al. 2005:62), the representations of the nativity of Jesus popular in Spain and the colonies at that time.

In late pre-Hispanic times the fine polychrome vessels with pictographic decoration were for a variety of ceremonial purposes (see Hernández 2005). Based on their shape, high quality and pictography, these vessels were probably serving wares for feasting; namely, ritualized events in which food and drink functioned as the main means of expression (see Bray 2003; Dietler 1996; Dietler and Hayden 2001:3). Those events are well-documented in Mesoamerica. Sahagún and Durán, for example, describe festivities of the ritual calendar, the 
government and other public celebrations in which big communal meals with special food, speeches, songs and other prescribed activities played a part e.g., Sahagún 1992, II: 121-122). It is also very possible that some vessels were containers for offerings of food, beverages or other substances, given the fact that in pre-Hispanic codices (e.g., Borgia 1993:8, 24, 45; Nuttall 1992:12) vessels with shapes similar to such polychrome ceramics appear as containers for food, burning resins, pulque, cacao or blood in diverse ceremonies. After the conquest, these vessels continued to be manufactured (Lind 1994:81). However, the pictography on these vessels became simpler and devoid of clear religious associations. The colonial eradication of public pre-Hispanic rituals and their associated visual symbols certainly modified the use and the context of these fine vessels. Probably they were still for special purposes, though of more mundane nature.

In brief, the early colonial vessel repertoire conserved many preHispanic shapes, although they frequently incorporated new morphological details, such as ring bases or lids, which were characteristic of the Spanish ceramic tradition. These added extras modified the appearance of the vessels but not their function, however. Some of the morphological elements with Spanish antecedent were not present in Late Aztec ceramics but in earlier examples. It seems that the collapse of the Aztec empire promoted more variability in decorative techniques and morphology of ceramics. That is, archaeological ceramic remains suggest that potters experimented more with new and ancient forms and techniques and produced more variety of vessels. In addition, the uses and contexts of several vessels of the indigenous repertoire had some modifications after the conquest. For example, Red Wares became more preferred to Black-on-Orange wares. The first became the most popular indigenous-style wares for serving while the latter were less produced and finally disappeared by the end of the early colonial period. Also orange molcajetes as well as red pitchers, cups and goblets became more popular after the conquest. This was not the result of new functions for the vessels but of new form preferences for known functions. It seems however that a number of Red Wares were actually associated to new colonial uses, for example, candeleros (candle holders), azucareras (sugar bowls), teteras (canes for tee or milk), which were incorporated in the new colonial society and reflect new domestic and eating habits. After the conquest indigenousstyle vessels were almost exclusively directed at domestic uses. Fine wares for special and ceremonial uses, such as polychrome vessels 
Table 1. Indigenous vessels' nomenclature in Nahuatl, English and Spanish registered in the tenth book of the Florentine Codex (Sahagún 1961, X:83).

\begin{tabular}{|c|c|c|c|c|c|}
\hline Nahuatl & English $^{\star}$ & Spanish $^{* *}$ & Nahuatl & English $^{*}$ & Spanish $^{* *}$ \\
\hline comitl & ollas & ollas & tlamamanalcaxitl & offering bowls & vasos \\
\hline paoazcomitl & cooking ollas & & tlamamanalcaxitl & offering bowls & vasos \\
\hline acomitl & water jars & tinajas & puchtecaiocaxitl & merchants' bowls & vasos \\
\hline tzotzocolli & large pitchers & cántaros & ticeoac & white bowls & vasos \\
\hline apilolli & jars for water & cantarillos & tlicaxitl & black bowls & vasos \\
\hline apaztli & $\begin{array}{l}\text { glazed pottery } \\
\text { basins }\end{array}$ & bacines & xomatli & ladles & cucharas \\
\hline tlalapaztli & earthen basins & & motziquâtli & combs & \\
\hline apantlecaxitl & large braziers & braseros & mulcaxitl & sauce bowls & \\
\hline tlauiltetl & candle holders & candeleros & ixtecqui & incised & \\
\hline caxitl & bowls & vasos & petzmucaxitl & $\begin{array}{l}\text { polished sauce } \\
\text { bowls }\end{array}$ & \\
\hline quauhcaxitl & wooden bowls & vasos & mulcaxpetztli & $\begin{array}{l}\text { sauce bowls } \\
\text { which have been } \\
\text { polished }\end{array}$ & \\
\hline petzcaxitl & polished bowls & vasos & tlemolcaxitl & $\begin{array}{l}\text { frying sauce } \\
\text { bowls }\end{array}$ & \\
\hline tlauhcaxitl & reddish bowls & vasos & tlatetzonilcaxitl & frying bowls & \\
\hline
\end{tabular}

* = According to the English translation from the original Nahuatl text of the Florentine Codex by Anderson and Dibble (Sahagún 1961:83).

${ }^{* *}=$ According to the corresponding text in Spanish in the Historia General of Sahagún (1992,X:571).

with pictographic decoration, were no longer made by the end of the early colonial period. Red vessels, or even Majolica, became the fine serving ware of that time and possibly replaced the vessels with pictography in some contexts; however they were not per se vessels for ceremony.

The tenth book of the Florentine Codex offers good insights into indigenous vessel nomenclature in Nahuatl (Sahagún 1961, X:83). Sahagún presents a list of the different clay objects made by potters and sold by dealers according to his indigenous collaborators. Thus, this list reflects the repertoire of vessels that were considered as indigenous in the second part of the sixteenth century; some of them were probably old objects no longer made but still present in the collective memory, while others were at that time in use. The names and categories of vessels are still pre-Hispanic (Table 1). Objects were named following different criteria, like use, material, method of decoration and visual aspect. Vessels for cooking and vessels for water were 
clearly separated. Also serving vessels had different names according to their use and appearance. Some of the names can now be associated with particular wares, for example, tlauhcaxitl, reddish bowls, were surely the vessels with red slip. However others were difficult to identify, for example, ticeoac, white bowls, or tlilcaxitl, black bowls, as the vessels' inventory did not include objects covered with white or black painting. In my opinion, offering bowls, white bowls and black bowls corresponded to different names given to the fine polychrome wares with pictographic decoration. In pre-Hispanic times these vessels were often painted with thematic complexes of motifs referring to sacrifice, to darkness or to white papers (see Hernández 2005). The list further indicates that molcajetes had several categories, probably because these vessels had different purposes and styles. In addition, included in the list are two Spanish-style objects: the apaztli, translated in the Historia General as bacines (Sahagún 1992,X:571), that is glazed pottery basins, as well as the tlauiltetl, candle holders or candeleros (Sahagún 1992,X:571). This shows that these two kinds of vessels were at that time already incorporated into the indigenous repertoire, and therefore they were made in indigenous-style workshops and received Nahuatl names.

The Códice de los Alfareros de Cuauhtitlan indicates, however, that vessels with a mixture of Spanish and indigenous antecedents and colonial innovations, received Spanish names, at least in contexts of contact with colonial authorities. For example, the codex refers to alcarrazas (bottle-like jars with globular body and tall neck), tinajas (amphorae with small lateral handles), and jarros picheles (pitchers with handle and stout and ring base). Also in that document is used the Spanish word jarros as a generic name for vessels, while grinding bowls, exclusive of the Mesoamerican tradition, are still called in Nahuatl molcaxetes. Some of the new early colonial names were connected to specific vessel shapes, thus when the objects disappeared the name was also lost. For example, neither the shape nor the name alcarraza or jarro pichel continue to be used at present. At the same time, a number of typical Mesoamerican vessels have conserved their Nahuatl name until today, though incorporated into Mexican Spanish language. This is the case of caxitl (bowl, today cajete), molcaxitl (grinding bowl, today molcajete), comalli (griddle, today comal), and tecomatl (today for spherical bowls, tecomate). On the other side, vessel shapes with Spanish origin and made with the potter's wheel 
received Spanish names, such as lebrillos (basins), bacines (basins with high walls), botijas (amphorae for olive oil), albarelos (high vases), tazas (cups) and candeleros (candle holders).

The list of clay objects made by potters and sold by dealers in the Florentine Codex shows that vessels were also categorized according to their manufacturing quality (see Table 1). In particular the list indicates that there were different kinds of low-quality vessels, for example, nanalca, [those which] sound cracked, tlemotzinqui, fired-cracked, aicucic, poorly fired, or tlaçacatlaxcaluilli, treated with yellow coloring, which Sahagún in the Historia General (1992,X:571) explains in this way: "porque no estaban bien cocidas échales algún color encima o tiñelas con amarillo." 10 This suggests that potters were extremely careful in the use of clay and fuel, and that imperfect vessels were also offered to the market. The same occurs at present, as clay and fuel are expensive and therefore potters have to economize as much as possible. It might be that this was also the case in early colonial times.

In addition, the introduction of the various Spanish systems of measures and weights and the colonial monetary system altered the nomenclature for vessels' sizes. Units for naming the sizes of the vessels and for selling were taken from the Spanish system. According to Hernán Cortés (1942, I:100), in the city markets of the conquest period, indigenous measures were used based on volume but not on weight. Although we do not know how the various dimensions of vessels were named in pre-conquest times, it seems that during colonial times names were incorporated that corresponded to the economic context at that time. This is evidenced by the fact that until the present time in regions of central Mexico some pots are called according to their price in the colonial monetary system. For example, today in Amozoc, Puebla the different sizes of ollas are called (from the biggest to the smallest): dos reales, de a real, de a medio (real), de a tres (cuartas, span of a hand), de a dos (cuartas, span of a hand), de a tlaco (in Nahuatl in the middle). In contrast, in San Miguel Tenextatiloyan, Puebla several sizes of cazuela are named according to the quantity of vessels por carga, per load: (from the biggest to the smallest) de a cuarenta (items por carga), de a cuatro (dozens por carga), de a seis (dozens por carga). The shifting to the carga (equal to two fanegas) occurred in the middle or late eighteenth century (Gibson 1964:357).

10 "Because they were not well fired they covered them with some color or painted them in yellow" (Sahagún 1992;X:571, my translation). 
In this case, naming also has reminiscences of the indigenous nomenclature, as the ancient vigesimal numeration is still involved. The use of the vigesimal system can also be seen in the Códice de los Alfareros de Cuauhtitlan, as it is written that the judge "... pagó un peso dos tomines (y medio) por veinte jarros que le dí (de) más ..."11 (Barlow 1951:7). Thus, present-day vessel size naming is a mixture of different systems and reflects the colonial intertwinement of various taxonomies, nomenclatures and methods of measuring.

In brief, during the early colonial period every stage of the production sequence of indigenous-style ceramics had different developments. Potters had diverse and complex reactions to the new situation. In some parts of the process of manufacturing they were highly creative and innovative, for example in decoration and morphological details. In other parts of the process they remained attached to their own techniques, as in the case of the forming method, even after a new forming method with new possibilities was introduced to Mesoamerica. Potters were well aware of the Spanish ceramic tradition. The Spaniards introduced new methods for making pottery and new decorative styles, but Mesoamerican potters incorporated them in variable degrees, as we will see below. Furthermore, the Spanish pottery technology not only inspired native potters, but also it became a source of social differentiation. It seems that indigenous-style workshops and Spanish-style workshops were maintained separately, as the dissimilar manufacturing techniques of indigenous-style and Spanish-style artifacts suggest. However, the context of use of the vessels of these two traditions, and their users, were not well differentiated, as we will see in the last part of this chapter.

\section{The impact of the Spanish ceramic technology}

In 1960 George Foster published Culture and Conquest: America's Spanish Heritage, one of the first studies on the effects of the Spanish conquest on indigenous material culture. For him, European techniques were obviously more advanced; therefore it was to be expected that native craftspeople adopted them, and that this promoted technological progress. However often in Mesoamerica, but also in other regions of the world, this was not the case. Thus, Foster devoted that

\footnotetext{
11 "He paid one peso and two tomines (and a half) for twenty pitchers I gave him extra" (Barlow 1951:7, my translation).
} 
work and further publications to explore why indigenous people did not accept European introductions (Foster 1959, 1962, 1967). This question reflected the evolutionistic thinking at that time. The ideas of Foster are now outdated; in more recent studies indigenous ceramic technologies are no longer seen as underdeveloped, rather than as other traditions with different trajectories as the European (e.g., Gasco 2005a; Lackey 1981; Papousek 1981). Still, the question of what aspects of the Spanish ceramic technology were incorporated by native potters is basic to obtain a deeper understanding of the interaction between indigenous and Spanish culture. After several decades of study of colonial artifacts (e.g., Charlton 1972, 1977; Charlton and Fournier 1993; Charlton et al. 1995, 2005, 2007; Fournier 1997; González Rul 1988; Gasco 1992; Rodríguez Alegría 2003, 2005) we now have more elements to offer an answer.

As in the case of Mesoamerica, ceramic-making had a large tradition in the Iberian Peninsula with several episodes of major transformations, such as the Roman period or the later Arabic period that extended from the eighth to the fifteenth centuries (see McEwan 1992; Sánchez 1994, 1996, 1998). Only a small part of that technology arrived in Mesoamerica. Shortly after Columbus founded a settlement in the Dominican Republic, ceramics from Seville arrived on the island (Deagan and Cruxent 2002:139-141). Later ceramics from that city were also shipped to Mexico (Sánchez 1996:132). However, the high costs of transportation, the growing number of Spanish settlers in the colonies, and especially the interest in maintaining the Spanish material culture, resulted in several Spanish potters being brought to Mexico City. At that time Seville was the port of embarkation for the transatlantic fleet and the place where the trade with the Americas was controlled, therefore it was a flourishing and wealthy metropolis. The neighboring town of Triana, specialized in ceramic manufacturing, was the place where the majority of the exported ceramics were made (Myers et al. 1992:131), and probably the origin of the potters who arrived in Mexico. This town underwent significant growth as the intercontinental trade expanded and the prosperous Seville society required more luxurious objects (Lister and Lister 1987:122). Due to limitations on transport, the majority of the ceramics that arrived in Mexico were containers (in particular olive oil jars) and serving wares (Sánchez 1998:122-123), in particular Majolica, at that time the favorite vessels for such a function. In Mexico, Spanish potters concentrated on the production of these wares as well, but they also made a 
few shapes necessary for maintaining the Spanish domestic culture, such as as candeleros or bacines. Thus, the ceramic technology that arrived in Mesoamerica from Seville, was associated to the manufacture of serving wares, and stylistically corresponded to the end of the Arabic decorative tradition and the beginnings of the renaissance in that region of Spain (Lister and Lister 1978; Sánchez 1998:127). This transition coincided with the political events of the sixteenth century in the Iberian Peninsula, such as the re-conquest of the last Muslim territories, the unification of kingdoms, and in general terms, the end of the Middle Ages (see Bartlett 1993:241-242).

It seems that Spanish-style workshops in Mexico City were maintained separately from indigenous-style workshops. This is recognized in the use of different methods of manufacture, different shapes and different decorations in vessels from both traditions. Despite that separation, native potters were well aware of the newcomer ceramic technology, and selectively incorporated and readapted various elements. Foster (1960:101-102) and other specialists (Gámez 2003:231; Martínez Peñaloza 1981:26; Müller 1973:98) emphasize that the Spaniards made three major introductions in Mesoamerica in relation to ceramic-making: the potter's wheel, the two-chamber kiln and the glaze. However, the wheel was not really implemented by native potters. As commented above, it seems that this method did not represent an improvement to the known technology, and therefore there was no reason to modify the most stable part of the production sequence, which was deeply rooted in potter families for generations and intimately associated to their own conceptualizations about pottery (Hernández 2008). The kiln was not a Spanish introduction. At least since the tenth century two-chamber updraft kilns were used in Tula, and, although other examples have not been found in central Mexico, there is no reason to believe that this was an exception. The lead glaze was indeed a novelty that attracted the attention of indigenous potters and was widely implemented early in the colonial period. This new decoration was showy and relatively easy to create. The mixture of lead oxide, silicate and clay in three equal parts was not difficult to produce once the potter knew the recipe. The problematic part was that vessels should be fired twice, and the second fire required enough temperature to reach the melting point of the glaze. However, it seems this was not a limitation as lead glazed indigenous-style vessels were broadly distributed in early colonial times, both in urban and rural contexts. This new form of decoration simplified the process 
of surface finishing as it was not necessary to burnish the vessel in detail; it also made the surface more impermeable. However, the glossy finishing was probably the most attractive quality for potters. Some early vessels were glazed in parts where economy of burnishing and water-resistance were not important criteria, for example, tripod molcajetes had glazed supports.

Decoration with lead glaze was without a doubt the aspect of the Spanish ceramic technology most implemented by native potters. Nevertheless, early colonial indigenous-style vessels also show other decorative elements taken from the Spanish tradition. The majority, however, were not copies of decorations on Spanish-style ceramics but reinterpretations of motifs depicted in other media or original creations derived from the New World brought by the Spaniards. A few colonial Red Wares were painted with a band of black curvilinear motifs which were alike, but not identical, to decorations on the Indígena wares, those early colonial vessels with white slip and lead glaze, considered by some specialists as native imitations of Majolica ceramics (Charlton et al. 2007:470-71; Lister and Lister 1978:21). Also that curvilinear decoration had some resemblance to motifs painted on the earliest Majolica wares in Mexico City (see Charlton et al. 2007:449,472-477). However this kind of adornment was rather exceptional; most of the new decorations with Spanish influence did not occur in Spanish-style vessels. For example, early colonial Blackon-Orange wares were painted with iconic images of flowers, fishes, birds, leaves and ears of wheat. Most of these images were not new in Mesoamerican ceramics but they were not painted before on these wares. Their style of representation was also a bit different to earlier figural depictions, and showed a little Spanish influence. In addition, the supports of these vessels were modeled in new shapes, some clearly inspired by colonial animals, like pig hoofs and lion claws.

In addition to decorative elements, indigenous potters also incorporated a few vessel shapes of the Spanish tradition. For example, extended plates or small cups with flat handles were the most common forms of Majolica wares (Charlton et al. 2007:463) while they, in that particular shape, were not made before in Mesoamerica. These vessels were incorporated into the wide early colonial repertoire of Red Wares. From their shape, they were for uses associated with Spanish domestic culture, but it seems that they also replaced Mesoamerican vessel forms with similar functions that became less popular after the conquest. The rest of the morphological novelties were details 
for embellishing the vessels rather than for modifying their function; for example, colonial Red Wares incorporated ring bases and cover lids that were characteristic of Spanish vessels at that time. In addition, as in the case of decoration, some morphological innovations were not imitations of European ceramics but were inspired by the new culture that arrived in Mesoamerica. This was clearly the case of the scarce jarros de negritos and the bowls with rim appendages modeled as faces of Spanish men represented in the Códice de los Alfareros de Cuauhtitlan.

However, a number of colonial innovations in decoration and morphology of indigenous-style ceramics were not associated with the European world. For example, early colonial potters incorporated in the inventory of Red Wares vessels decorated with grooving, differential polishing, incrustations and stamping, but these techniques were not used in Spanish ceramics. In addition, several decorative elements and morphological details that in pre-Hispanic times were exclusively associated to particular wares, appeared after the conquest in other kinds of vessels. For example, colonial Black-on-Orange wares incorporated decorative patterns that in the Late Aztec period were exclusive of Red Wares. Black-on-Orange vessels also presented supports that in pre-Hispanic times were exclusive of polychrome vessels with pictographic decoration. These novelties and the flexibility of decorative canons were possibly related to the collapse of the Aztec empire which it seems promoted more creativity among potters. That is, not all changes manifested in colonial vessels were a consequence of the encounter with the Spanish material culture. In my opinion, the conquest did not interrupt, but rather altered, the trajectories of indigenous ceramic technology.

Thus, Mesoamerican potters openly and selectively incorporated or reinterpreted a number of elements of Spanish ceramic technology, in particular in vessel decoration and morphology. They were also inspired by the new colonial world and created new decorative compositions, which were more figural and iconic than in pre-Hispanic times. In contrast, Spanish ceramic technology adopted practically nothing from the indigenous tradition, neither in Seville nor in Mexico City. People associated with the colonial rule in the valley of Mexico used indigenous-style pottery. For example, many Red Wares have been found in La Traza (Rodríguez Alegría 2003), the most prominent area of the city, and also in churches and convents in the valley of Mexico and elsewhere. However, Spanish-style workshops 
apparently did not produce vessels of the indigenous tradition. This is suggested by the lack of indigenous-style vessels made with the wheel. The reasons for this rejection might be in part related to the colonial situation; namely, the unequal power relations between colonizers and colonized, the conviction of European technological superiority, and the need of the colonizers to maintain the cultural association with their fatherland. However, part of the reason was probably of a technical nature. As was the case for Mesoamerican-style workshops, Spanish-style workshops were attached to their own methods of manufacture.

In brief, early colonial Mesoamerican potters had various reactions to Spanish technology. On the one hand, they selectively incorporated and reinterpreted elements of decoration and morphology, and were inspired by the world brought by the Spaniards in the creation of new decorative motifs. On the other, they did not implement technical devices that did not accord to their necessities, such as the potter's wheel. In my opinion, the inclusion of Spanish decorative elements in the vessels was not related to attitudes of submission, just as the rejection of Spanish devices was not related to attitudes of subversion. Potters worked following the same dynamics as in ancient times, that is, they conserved their familiar methods of forming while they adapted the visible aspects of the vessels to the situation of the present time. These two basic characteristics, existing at the same time, are evident in the entire ceramic production of the pre-Hispanic history. Thus, in the early colonial period the incorporation, adaptation or rejection of Spanish elements was not politicized by potters. They just wanted to maintain their way of living and adapt to the new postconquest society.

\section{Ceramics as indices of cultural affiliation in early colonial central Mexico}

The equation of a ceramic complex with a social group is a problematic task in archaeology. Objects may be associated with cultural affiliation (Aztec-style ceramics are Aztec ceramics), and with uses distinctive of that culture (Aztec-style ceramics are for Aztec uses), but in practice we recognize that the relationship between objects, users and uses is more complex. In the reconstruction of colonial encounters the correlation of some objects with colonizers and others 
with the colonized can be particularly misleading. On the one hand, colonial societies were heterogeneous and included a variety of social groups beyond the categories of native and foreign peoples. On the other, material culture in those situations also had a variety of associations, meanings and contexts, so that it could not simply be pigeonholed in the dichotomy native $v s$. foreign (for a recent discussion see Voss 2008). For example, in central Mexico early colonial ceramics cannot just be divided into two groups, indigenous $v s$. Spanish. The repertoire was composed of several kinds of vessels which according to their provenance, manufacturing method, shape and decoration had different ties to the various components of the colonial society. According to these aspects, ceramic vessels can be better arranged in a continuum in which the two extremes are clearly differentiated. On the one side, we can group the ceramics made in Mesoamerica with native technology and no Spanish or colonial influence. On the other, we can group the Majolica wares made in Spain and exported to the Americas, but in between there were several wares with variable associations to the native and foreign cultures. Even in the case of these two extremes we cannot make an unambiguous correlation between indigenous ceramics and indigenous users and Spanish ceramics and Spanish users, as we know there were exceptions. For example, indigenous nobility used Spanish-style ceramics (e.g., Lind 1987:111) while in the houses of prominent colonial authorities indigenous-style wares were used (e.g., Rodríguez Alegría 2005).

The regulations of the potters' guild from 1653 indicate that colonial authorities made a distinction between fine grade Majolica ware, common grade Majolica ware and loza amarilla (lead glazed ware), while the rest of the ceramics produced in Mexico were just considered apart and ignored in the regulations. At that time guilds were created to protect industries and craftspeople closely associated to the colonizers' culture (Carrera Estampa 1954). Thus, these three kinds of ceramics were seen as components of that culture. Although we do not have documentary references on how the remaining ceramics were categorized, we can recognize several well-differentiated wares according to the method of manufacture, shape and decoration. Every one of these wares had particular connections with the colonial culture. At one extreme of the list we place the simple vessels for domestic purposes made in Mesoamerica with pre-Hispanic forming methods and style, which incorporated minor morphological alterations after the conquest but were not the result of Spanish influence or 
of notable modifications in function. This was the case of jars, bowls and comales. The second group is composed of the Black-on-Orange vessels which were clearly a continuation of the popular Late Aztec serving wares but incorporated new decorations inspired by the colonial culture. In a third group we include domestic wares made by mold with indigenous shapes but decorated with lead glazing, a clear Spanish introduction. This was the case of molcajetes, pitchers and small jars. In a fourth group we have the Red Wares which were made by mold and were a continuation of the pre-Hispanic red vessels but show notable colonial creativity. New shapes and decorations were introduced; a few of them were taken from the Spanish ceramic tradition but others were colonial innovations. Then we have those ceramics which the guild regulations associated with the colonizers' culture. Thus, a fifth group includes domestic lead glazed vessels made by wheel with Spanish-style shapes. The sixth group consists of the Majolica wares produced in Mexico City, made by wheel and with Spanishstyle shapes and decoration. And finally, at the other extreme of the list, we have Majolica and porcelain wares imported from Europe and Asia.

At the beginning of the colonial domination, Spanish-style objects, such as Majolica wares and lead glazed vessels, were for Spanish use as their purpose was to preserve domestic habits of the fatherland. However, by the early seventeenth century society became more heterogeneous and social position was not only determined by cultural affiliation but also by social and economic position (Lockhart 1992:433). In this context many Spanish-style objects became elements for indicating the own social place (Gibson 1964:153-156). It seems this was the case of Majolica wares. They continued being associated with the colonizers' culture but they were not exclusively used by those representing that culture. They were often used by colonial authorities or persons with Spanish antecedent. The archeological distribution of these objects shows that they were common in locations related to the colonizers' culture, such as churches, convents and houses of authorities (e.g., Fournier 1990; Lister and Lister 1978; López Cervantes 1982), but they were also present in, for example, Tlatelolco, an indigenous sector of the city (see Charlton et al. 2005:463-469). In addition, the use of Majolica wares was an urban phenomenon in the valley of Mexico, as the city was the place of direct interaction between the indigenous and the Spanish cultures. 
However, a few fragments of these wares have been also found in rural locations in the Otumba region (Charlton et al. 2005:58).

Red Wares had a different status. They were visibly a continuation of pre-Hispanic ceramics, and their method of manufacture, shape and decoration was distinctive of the pre-Hispanic tradition. However, after the conquest they evidence a creative impulse, as they incorporated many new shapes and decorations; some of them associated with colonial culture. The the Códice de los Alfareros de Cuauhtitlan shows that four decades after 1521 Red Wares continued to be made in indigenous settlements, and they were also requested by colonial authorities, like the alcalde mayor of that town. The archeological distribution of Red Wares also evidence that they were used in various sectors of colonial society. For example, they were frequent in Tlatelolco (Charlton et al. 1995), but as Rodríguez Alegría investigated (2005:560-563), they were also present in houses of La Traza associated with prominent families of the colonial administration. A review of ceramic collections from several places in the valley of Mexico shows that they occurred as well in churches and convents, such as the Metropolitan cathedral and the convents of Bethlemitas and San Jerónimo. Their popularity extended even beyond the valley of Mexico, as they were frequent in, for example, convents of Cholula (Müller 1973; Plunket et al. 1994; Sáenz 2004) and the palace of Cortés in Cuernavaca (Charlton et al. 1995:150). They were frequent in urban contexts although they have also been found in the rural area of Otumba (Charlton et al. 2005:59). In comparison to Black-on-Orange ceramics, Red Wares became the favorite indigenous-style serving wares in early colonial times. The colonial shapes and decoration show that they were adapted to the new colonial necessities (e.g., candle holders, Spanish-style plates, cups) but could also be used for pre-Hispanic functions (e.g., molcajetes). In that way they could satisfy the necessities of a variety of people.

The situation of Black-on-Orange wares was different. They were a direct continuation of the typical Late Aztec wares. Although they incorporated a few new decorations and morphological details inspired by the new colonial world, they were less produced after the conquest and disappeared by the end of the early colonial period. These ceramics were not adapted to the new colonial preferences. That is, after the conquest there were no innovations in vessel shapes. The archeological distribution of Black-on-Orange wares suggests that 
they were more common in contexts related to indigenous culture, such as Tlatelolco and Otumba (Charlton et al. 2007:439-440).

Thus, in the early colonial valley of Mexico, ceramics were not clear indices of cultural affiliation. Likely wares associated by style and function to the Spanish world were characteristic of contexts related to that culture. In the same way, vessels associated by style and function to the indigenous world were more frequent in contexts related to that culture. Nevertheless, some ceramics, such as Red Wares and lead glazed vessels made with indigenous techniques, were in-between. They were adapted to colonial society, and for this reason, they had a variety of users and contexts of use.

\section{Early colonial ceramics in central Mexico}

After the conquest the pre-Hispanic ceramic tradition from central Mexico persisted. The collapse of the Aztec empire, the new colonial society, and the introduction of the Spanish ceramic tradition did impact native technology, but it was different for every stage of the production sequence of ceramic vessels. The part of the sequence more deeply rooted in potters and more directly tied to their own conceptions on pottery-the method of manufacture-was maintained without change. In contrast, other parts of the production sequence, more visible and flexible, like surface finishing, decoration and assembling the vessel repertoire, had modifications and evidenced great colonial creativity. A few innovations were the direct result of the influence of the Spanish ceramic tradition. For example, the most important novelty in decoration was the lead glaze, a Spanish introduction. It attracted the attention of indigenous potters and users, so that early in the colonial period it was widely implemented in central Mexico. However, the majority of the decorative innovations were a consequence of new ideas inspired by the colonial world. This was the case of motifs painted on Black-on-Orange wares representing animals and plants brought by the Spaniards. Also the indigenous vessel inventory incorporated a few new shapes taken from the Spanish inventory; however many morphological innovations were minor details for embellishing the vessels not present either in Spanish or in Late Aztec ceramics.

The basic pre-Hispanic vessel repertoire for domestic activities was maintained without important changes. These artifacts were not mod- 
ified to satisfy the necessities of the new Spanish settlers. For that purpose the colonizers first brought ceramics from Seville, and then Spanish potters who established workshops in Mexico City. They manufactured Spanish-style vessels using the Spanish forming method (the potter's wheel), and shaped and decorated them in the same way as in Spain. Thus, indigenous and Spanish ceramic traditions existed at the same time but were maintained separately, and for this reason, their products maintained their own dynamics of development. It has been suggested that indigenous domestic ceramics deteriorated after the conquest, as the surface finishing of orange jars and bowls was less carefully done (e.g., Charlton et al. 2005:58), but in my opinion this was not the case. Early colonial potters preferred to finish the surface of common jars and bowls with lead glaze rather than with burnishing. Thus, as glazed vessels became more popular, burnished vessels were less produced, but this process of replacement has not been recognized.

In contrast to cooking vessels, the early colonial repertoire of serving wares manifested great formal creativity. Many new vessel shapes were introduced, although the majority was not for new functions, but rather to replace earlier vessels of similar functions. Many of the new shapes incorporated morphological details from the Spanish tradition, such as lids or ring bases, while typical pre-Hispanic elements, such as tripod supports, were suppressed. In that way serving wares developed a distinctive colonial style. Red Wares became the favorite vessels for eating and drinking while Black-on-Orange wares became much less frequent and finally disappeared. Colonial serving vessels were often decorated, although not in the same way as in pre-Hispanic times. The most popular decoration became the red slip with a variety of surface treatments. In contrast, the typical Late Aztec decoration, black painting on an orange surface, became less frequent. Also vessels with pictographic decoration became very scarce after the conquest. Their motifs became simpler, less varied and less associated to ritual/religious meanings, thus it seems that the function of decoration on ceramics changed. Fine polychrome vessels were no longer media of literacy. In pre-Hispanic times these fine vessels were serving wares for special occasions, like feasting, but they were also used as containers in other ritual activities such as offering ceremonies or funerary rituals (see Hernández 2005). The changes in their decoration after the conquest suggest that these vessels were no longer openly created for ritual purposes. In addition, vessels for exclusive ritual 
purposes, like censers, disappeared after the conquest, although there is rare evidence of their manufacture and use in the first colonial years.

The system of interregional trade of ceramics collapsed after the conquest. This was a consequence of the end of the Aztec empire and the disintegration of trade routes. In prominent contexts the new Spanish-style ceramics took the place of the earlier luxury objects from other parts of Mesoamerica. Thus, the early colonial ceramic repertoire in the valley of Mexico was formed by several kinds of vessels produced for the most part in that region. On the one side, there were Spanish-style vessels. On the other, there was a variety of indigenous-style ceramics, which incorporated new shapes of decorations after the conquest. They maintained, however, many pre-Hispanic elements. Some of them were clearly visible, such as the red slip of Red Wares, or the shape of cooking objects but others were not visible, such as the use molds for forming vessels. Nevertheless, all these traits show that the conquest did not interrupt the transmission of knowledge in potter families. 